\title{
CORRECTIVE ACTION BASELINE REPORT FOR UNDERGROUND STORAGE TANK \\ 2331-U AT THE BUILDING 9201-1 SITE
}

\author{
OAK RIDGE Y-12 PLANT \\ OAK RIDGE, TENNESSEE \\ FACILITY ID \#0-010117
}

\author{
January 1994 \\ Environmental Management Department \\ Health, Safety, Environment, \\ and Accountability Organization
}

\footnotetext{
Prepared by

Science Applications International Corporation Under Subcontract 18B-99069C for the Oak Ridge Y-12 Plant Oak Ridge, Tennessee 37831

Managed by

Martin Marietta Energy Systems, Inc. for the U.S. Department of Energy Under Contract No. DE-AC05-84OR21400
} 


\section{DISCLAIMER}

This report was prepared as an account of work sponsored by an agency of the United States Government. Neither the United States Government nor any agency thereof, nor any of their employees, make any warranty, express or implied, or assumes any legal liability or responsibility for the accuracy, completeness, or usefulness of any information, apparatus, product, or process disclosed, or represents that its use would not infringe privately owned rights. Reference herein to any specific commercial product, process, or service by trade name, trademark, manufacturer, or otherwise does not necessarily constitute or imply its endorsement, recommendation, or favoring by the United States Government or any agency thereof. The views and opinions of authors expressed herein do not necessarily state or reflect those of the United States Government or any agency thereof. 


\section{DISCLAIMER}

Portions of this document may be illegible in electronic image products. Images are produced from the best available original document. 


\section{CORRECTIVE ACTION BASELINE REPORT}

1.0 INTRODUCTION

1.1 Purpose and Scope

1.2 Site Description.

1.3 Progress Summary

2.0 ANALYTICAL RESULTS

2.1 Groundwater Sample Collection and Analysis

2.1.1 New and Existing Well Locations.

2.1.2 Groundwater Sampling

2.1.3 Sample Analysis.

2.2 Groundwater Data Evaluation

2.2.1 Baseline Sampling Analysis Results.

2.2.2 Changes in Contaminant Extent.

2.3 Confirmatory Soil Sampling

3.0 ZONE OF INFLUENCE .................................................... 12

3.1 Baseline Hydrogeologic Conditions ...................................... 12

3.1.1 Water Level Measurements ......................................... 12

3.1.2 Potentiometric Surface........................................................ 12

3.2 Adjusted Zone of Influence ................................................ 12

\section{APPENDICES}

Appendix A Monitoring Well Installation and Development Reports................. A-1

A.1 GW-808......................................................... A-2

A.2 GW-809............................................................ A-8

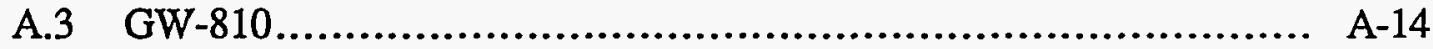

Appendix B Laboratory Analytical Results for Baseline Groundwater Sampling ...... B- B-1

B.1 Groundwater Sample Analytical Results ................................ B-2

B.2 Quality Control Sample Analytical Results.................................. B-10 


\section{LIST OF FIGURES}

Figure Title Page

1-1 Building 9201-1 Site .............................................. 2

2-1 Building 9201-1 Site Monitoring Well Location Map....................... 8

2-2 Building 9201-1 Site Baseline Zone of Influence of Benzene \& TPH

3-1 Building 9201-1 Site Groundwater Potentiometric Contour Map

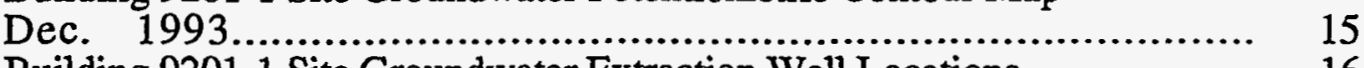

\section{LIST OF TABLES}

Table Title Page

1-1 Chronological Summary of Events at the Building 9201-1 Site ............. 3

1-2 Planned/Actual Schedule for Corrective Action Activities ....................

2-1 Groundwater Monitoring Well Details at the Building 9201-1 Site............ 8

2-2 Baseline Groundwater Analytical Results, November 2, $1993 \ldots \ldots \ldots \ldots \ldots . \quad 10$

3-1 Water Level Measurements............................................ 14 


\section{LIST OF ACRONYMS}

UST underground storage tank

TDEC Tennessee Department of Environment and Conservation

CAP corrective action plan

TPH-GRO

BTEX

total petroleum hydrocarbons - gasoline range organics

benzene, toluene, ethylbenzene, and xylene 


\subsection{INTRODUCTION}

\subsection{PURPOSE AND SCOPE}

The purpose of this report is to provide baseline geochemical and hydrogeologic data relative to corrective action for underground storage tank (UST) 2331-U at the Building 9201-1 Site. This report has been prepared in accordance with the requirements of the Tennessee Department of Environment and Conservation (TDEC) Rule 1200-1-15, the TDEC UST Reference Handbook (TDEC 1992), and the approved revised corrective action plan (CAP) for this site (Energy Systems 1993). Progress in support of the Building 9201-1 Site has included monitoring well installation and baseline groundwater sampling and analysis.

This document represents the baseline report for corrective action at the Building 9201-1 site and is organized into three sections. Section 1 presents introductory information relative to the site, including the regulatory initiative, site description, and progress to date. Section 2 includes the summary of additional monitoring well installation activities and the results of baseline groundwater sampling. Section 3 presents the baseline hydrogeology and planned zone of influence for groundwater remediation.

\subsection{SITE DESCRIPTION}

The Building 9201-1 Site is located within the south central portion of the Exclusion Zone at the Oak Ridge Y-12 Plant. The site is generally defined as the area directly south of the concrete ramp/loading dock on the east side of Building 9201-1 (Figure 1-1). The site was previously the location of an active 560 gallon gasoline storage tank and dispensing pump used to fuel gasoline-powered equipment in the area. The tank has been excavated and removed from the site.

The topography of the Building 9201-1 Site gently decreases in elevation from north to south across the facility and any petroleum contamination resulting from past operations would be expected to migrate to the south/southeast away from the source area. A summary of the major events related to the tank at the site is presented in Table 1-1.

\subsection{PROGRESS SUMMARY}

Preceding TDEC approval of the Revised CAP in December 1993, steps were taken to implement the soil and groundwater corrective action at the site. In addition to monitoring well GW-193, installed during 1989, and GW-657, GW-707, and GW-708 installed in 1990, three groundwater monitoring wells were installed downgradient of the projected contaminant plume to complete delineation in accordance with the CAP. Monitoring wells GW-808, GW-809, and GW-810 were installed during late July 1993. These seven wells were sampled on November 2, 1993 and analytical results were received on November 29, 1993. Water level measurements for baseline hydrogeologic interpretation were taken in December 1993.

Activities completed to date are following the implementation schedule presented in the revised CAP. A comparison of the planned versus actual/projected dates for completion of milestone corrective action activities is presented in Table 1-2. A staged approach to installation of the groundwater recovery system will be pursued in order to limit or prevent continued migration of contaminants along the downgradient margins of the groundwater plume. Existing wells and/or installed extraction wells will be used for groundwater recovery. 
Table 1-1 Chronological Summary of Events at the Building 9201-1 Site

1972 Underground storage tank 2331-U installed and placed into service at the Building 9201-1 Site.

1988 Tank 2331-U is tested for tightness in response to reports of gasoline vapors. Tightness test results indicated leakage in excess of regulatory allowable rate of $0.1 \mathrm{gal} / \mathrm{h}$. The tank was removed and soil samples were analyzed.

1989 Initial Site Characterization Report and Site Investigation Plan was approved by the TDEC. Well GW-193 installed to determine if free product migration had occurred. A soil gas survey and slug test were performed as part of Initial Site Characterization Report and Site Investigation Plan activities.

1990 Field work for the Site Investigation began in July. Soil borings and groundwater monitoring well installation and sampling were performed.

1992 Original Corrective Action Plan submitted to TDEC.

1993 TDEC identifies deficiencies with the CAP and requests a revision. Revised CAP submitted and subsequently approved by TDEC. Installation of three downgradient groundwater wells. 


\section{Table 1-2 Planned/Actual Schedule for Corrective Action Activities}

\begin{tabular}{|c|c|c|}
\hline Corrective action activity & Planned date & $\begin{array}{l}\text { Actual/ } \\
\text { projected date }\end{array}$ \\
\hline TDEC Approval of Revised CAP & N/A & $12 / 7 / 93$ \\
\hline $\begin{array}{l}\text { Begin Installation of Additional Site Monitoring } \\
\text { Wells, and Sampling and Analysis of Groundwater }\end{array}$ & $1 / 21 / 94$ & $7 / 21 / 94$ \\
\hline Receipt of Groundwater Analytical Data & N/A & $11 / 29 / 93$ \\
\hline Receipt of Wet Season Water Level Measurements & N/A & $12 / 13 / 93$ \\
\hline Issue Baseline Report & $1 / 13 / 94$ & $\sim 1 / 18 / 94$ \\
\hline $\begin{array}{l}\text { Issue Bid Specifications for Procurement of Thermal } \\
\text { Desorption Services }\end{array}$ & $2 / 1 / 94$ & - \\
\hline Begin Soil Excavation & $2 / 18 / 94$ & - \\
\hline Begin Installation of Groundwater Recovery System & $2 / 18 / 94$ & - \\
\hline $\begin{array}{l}\text { Begin Operation of Groundwater Recovery System } \\
\text { and Treatment of Contaminated Groundwater }\end{array}$ & $3 / 18 / 94$ & - \\
\hline $\begin{array}{l}\text { Issue First Monthly Report on Progress and Field } \\
\text { Sample Analysis (if available) }\end{array}$ & $\begin{array}{l}\text { Within } 45 \text { days } \\
\text { soil excavation }\end{array}$ & As scheduled \\
\hline Begin Aeration Treatment of Contaminated Soils & $\begin{array}{l}\text { Within } 60 \text { days } \\
\text { contract award }\end{array}$ & As scheduled \\
\hline $\begin{array}{l}\text { Issue Second and Third Monthly Reports on } \\
\text { Progress and Field Sample Analysis }\end{array}$ & $\begin{array}{l}\text { Monthly after } \\
\text { first report }\end{array}$ & As scheduled \\
\hline $\begin{array}{l}\text { Issue Quarterly Reports on Progress and } \\
\text { Field/Treatment Sample Analyses }\end{array}$ & Quarterly & As scheduled \\
\hline Issue Final Corrective Action Report & $\begin{array}{l}\text { Within } 90 \text { days } \\
\text { completion }\end{array}$ & As scheduled \\
\hline
\end{tabular}




\subsection{ANALYTICAL RESULTS}

\subsection{Groundwater Sample Collection and Analysis}

\subsubsection{New and Existing Well Locations}

At present, seven groundwater monitoring wells are located south and east of the location of the former UST 2331-U. The location of the monitoring wells used in the groundwater monitoring at the facility are presented in Figure 2-1. Three wells were installed prior to approval of the revised CAP in December 1993. These wells are GW-808, GW-809, and GW-810, which were installed July 1993 . The additional wells extend groundwater monitoring coverage to the east and south of the facility. Well installation reports for wells GW-808, GW-809, and GW-810 are contained in Appendix A. Well details for the seven groundwater monitoring wells are listed in Table 2-1.

\subsubsection{Groundwater Sampling}

The groundwater monitoring wells at the Building 9201-1 Site were sampled for baseline data on November 2, 1993. Wells were purged for three well volumes with field measurement of $\mathrm{pH}$, conductivity, temperature, and dissolved oxygen during the purging operation to ensure representativeness for sampling. The wells were allowed to recover and samples were collected for analysis in pre-prepared bottles.

\subsubsection{Sample Analysis}

Samples were analyzed for total petroleum hydrocarbons for gasoline range organics (TPH-GRO) and for benzene, toluene, ethylbenzene, and xylene (BTEX). Analytical results for the November 1993 sampling event are summarized in Table 2-2 with laboratory reports presented in Appendix B.

\subsection{Groundwater Data Evaluation}

\subsubsection{Baseline Sampling Analysis Results}

Analytical data to support delineation of the ground water contamination at the Building 9201-1 Site has been collected through the Site Investigation in October 1990 and as part of the Y-12 Plant Groundwater Quality Assessment Program during the years 1990 and 1991. Data generated from these investigations are presented in Appendices F and G of the revised CAP. Based on results of previous groundwater quality investigations, the groundwater at the Building 9201-1 Site is classified as a nondrinking water source. According to this classification, the TDEC closure action levels for groundwater at the Building 9201-1 Site are $0.070 \mathrm{ppm}$ for benzene and $1.0 \mathrm{ppm}$ for TPH. Analytical results from the baseline sampling event that exceed the TDEC Closure Action Limits are indicated with an asterisk in Table 2-2.

Groundwater samples analyzed from wells GW-193, GW-707, and GW-708 have historically produced groundwater samples with analysis in excess of the $0.070 \mathrm{ppm}$ benzene Closure Action Levels for contaminated groundwater and these limits were again exceeded with samples from the November, 1993 baseline sampling in wells GW-193 and GW-707. Analysis of samples collected from the remaining wells, GW-657, GW-708, GW-808, GW-809, and GW-810 did not exceed the TDEC Closure Action Limits. 
Table 2-1 Groundwater Monitoring Well Details for the Building 9201-1 Site

\begin{tabular}{|c|c|c|c|c|c|c|c|c|c|c|}
\hline Well \# & $\begin{array}{l}\text { Aquifer } \\
\text { Zone }\end{array}$ & $\begin{array}{l}\text { Well } \\
\text { Depth }\end{array}$ & $\begin{array}{l}\text { T.O.C. } \\
\text { Elevation } \\
\text { (MSL) }^{2}\end{array}$ & $\begin{array}{l}\text { Surface } \\
\text { Elevation } \\
\text { (MSL) }\end{array}$ & $\begin{array}{l}\text { Installation } \\
\text { Date }\end{array}$ & $\begin{array}{c}\mathrm{WL}^{3} \\
\text { Readings }\end{array}$ & $\begin{array}{l}\text { Time } \\
\text { Frame }\end{array}$ & $\begin{array}{l}\text { Average } \\
\text { WL Depth } \\
\text { BTOC }^{4}\end{array}$ & $\begin{array}{l}\text { High } \\
\text { WL } \\
\text { BTOC }\end{array}$ & $\begin{array}{c}\text { Low } \\
\text { WL } \\
\text { BTOC }\end{array}$ \\
\hline GW-193 & $\mathrm{WT}^{5}$ & 18.4 & 934.00 & 931.11 & $8 / 89$ & 11 & $1990,91,92,93$ & 5.73 & 5.31 & 6.36 \\
\hline GW-657 & WT & 17.1 & 930.53 & 930.80 & $10 / 90$ & 9 & $1991,92,93$ & 6.30 & 5.27 & 7.25 \\
\hline GW-707 & WT & 26.0 & 930.91 & 931.16 & $10 / 90$ & 9 & $1991,92,93$ & 6.02 & 5.25 & 6.35 \\
\hline GW-708 & WT & 13.9 & 930.87 & 931.03 & $10 / 90$ & 9 & $1991,92,93$ & 5.07 & 4.51 & 5.51 \\
\hline GW-808 & WT & 40.4 & 930.75 & 931.24 & $7 / 93$ & 1 & $12 / 1993$ & $8.05^{6}$ & $\mathrm{NA}^{7}$ & NA \\
\hline GW-809 & WT & 40.0 & 931.04 & 931.27 & $7 / 93$ & 1 & $12 / 1993$ & $8.81^{6}$ & NA & NA \\
\hline GW-810 & WT & 26.8 & 931.44 & 931.68 & $7 / 93$ & 1 & $12 / 1993$ & $8.67^{6}$ & NA & NA \\
\hline
\end{tabular}

${ }^{1}$ Top of Casing

${ }^{2}$ Mean Sea Level

${ }^{3}$ Water Level

${ }^{4}$ Below Top of Casing

${ }^{5}$ Water Table

6December, 1993 measurement only

${ }^{7}$ Not Applicable 
Table 2-2 Baseline Groundwater Analytical Results, November 2, 1993

\begin{tabular}{cccccc}
\hline WELL\# & $\begin{array}{c}\text { TPH-GRO } \\
(\mathrm{ppm})\end{array}$ & $\begin{array}{c}\text { Benzene } \\
(\mathrm{ppm})\end{array}$ & $\begin{array}{c}\text { Ethyl- } \\
\text { benzene } \\
(\mathrm{ppm})\end{array}$ & $\begin{array}{c}\text { Toluene } \\
(\mathrm{ppm})\end{array}$ & $\begin{array}{c}\text { Xylene } \\
\text { (ppm) }\end{array}$ \\
\hline GW-193 & $5.50^{*}$ & $1.68 \mathrm{E}^{*}$ & 0.575 & 0.235 & 0.353 \\
GW-657 & $<0.100$ & $<0.001$ & $<0.001$ & $<0.001$ & $<0.001$ \\
GW-707 & $7.50^{*}$ & $0.900^{*}$ & 0.800 & 0.095 & 1.575 \\
GW-708 & $<0.100$ & $<0.001$ & $<0.001$ & $<0.001$ & $<0.001$ \\
GW-808 & 0.140 & $<0.001$ & 0.016 & $<0.001$ & 0.111 \\
GW-809 & $<0.100$ & 0.001 & 0.003 & 0.001 & 0.016 \\
GW-810 & 0.190 & 0.001 & 0.019 & 0.001 & 0.136 \\
\hline
\end{tabular}

$\mathrm{E}=$ benzene exceeded calibration range

*The closure action levels at the Building 9201-1 Site are TPH-1..0 ppm; benzene $-0.070 \mathrm{ppm}$ 


\subsubsection{Changes in Contaminant Extent}

The analytical results confirm the lateral extent of contamination as previously delineated in the revised CAP (Energy Systems, 1993). The additional data from the 1993 installed wells (GW-808, GW-809, and GW-810) suggests a slight extension of the contamination area further to the south toward the GW-808 location (Figure 2-2) based on observed contaminant concentrations. The contaminant plume does not appear to extend to the location of GW-809, GW-810, or further south to GW-657, as indicated by the low level values for benzene and TPH. Migration of the contaminant plume is also indicated by the nondetection of contaminants in GW-708, a monitoring well with a previous history of contamination.

\subsection{Confirmatory Soil Sampling}

Soil excavation activities have not been initiated at the tank 2331-U site. Confirmatory sampling in accordance with the revised CAP will be conducted during soil corrective action. The results of this sampling will be reported in subsequent progress reports. 


\subsection{ZONE OF INFLUENCE}

\subsection{Baseline Hydrogeologic Conditions}

Mapping of the potentiometric surface based on seasonal water level measurements obtained during May and June 1990 and 1992 indicated groundwater generally flows from the north/northwest to the south/southeast across the Building 9201-1 Site (Energy Systems 1993). Additional measurement of water levels was made prior to the issuance of this report to confirm established trends and update potentiometric maps with data from recently installed wells.

\subsubsection{Water Level Measurements}

Water level measurement for the seven groundwater monitoring wells at the Building 92011 Site are listed in Table 3.1. Water level measurements were taken in late December 1993 and therefore correspond closely to the expected fall/winter water levels.

\subsubsection{Potentiometric Surface}

Mapping of the groundwater potentiometric surface present at the Building 9201-1 Site based on the December 1993 data confirms water flows to the south-southeast across the site (Figure 3.1). Average water level data are not available for the recently installed wells thus a comparison of winter levels to May/June levels has not been performed. A comparison of Figure 3.1 to the potentiometric surface presented in the approved CAP reflects the control of the additional water levels from wells GW-808, GW-809, and GW-810. The December water level data suggest a strong southerly component to groundwater flow southeast of the UST site. It should be noted the configuration of the contours reflects a single event measurement and is representative of the seasonal water table.

\subsection{Adjusted Zone of Influence}

The delineated area of hydrocarbon contamination (Figure 2.2) is supported by the projected groundwater flow as contoured in Figure 3-1 and validated by groundwater samples from the seven groundwater monitoring wells. Therefore, adjustment of the zone of influence, as depicted in the approved CAP, has been performed. The adjusted zone of influence (Figure 3-2) occupies an area of approximately $2,296 \mathrm{ft}^{2}$. Assuming an effective aquifer depth of $8 \mathrm{ft}$ and $10 \%$ porosity in the saturated soil, the current contaminated groundwater volume is estimated to be approximately 13,730 gallons.

The planned zone of influence of the groundwater recovery system will be sufficient to encompass the current area of contaminated groundwater without adjustment of the planned location of the extraction wells, as depicted in the CAP and Figure 3-2 of this document. The actual drawdown produced by the groundwater recovery system will be mapped and presented in subsequent status reports following implementation of groundwater corrective action. Any deficiency in the zone of influence of the groundwater recovery system will be corrected by adjusting pumping rates or utilization of existing wells to complement the recovery system. 
Table 3.1 Water Level Measurements-Building 9201-1 Site

\begin{tabular}{cccccc}
\hline $\begin{array}{c}\text { Monitoring } \\
\text { Well \# }\end{array}$ & $\begin{array}{c}\text { Date } \\
\text { Measured }\end{array}$ & $\begin{array}{c}\text { Total Well } \\
\text { Depth } \\
(\mathrm{BGL})\end{array}$ & $\begin{array}{c}\text { Top of } \\
\text { Casing } \\
(\mathrm{MSL})^{2}\end{array}$ & $\begin{array}{c}\text { Top of Casing } \\
\text { to Water Level } \\
(\mathrm{BTOC})^{3}\end{array}$ & $\begin{array}{c}\text { Potentiometric } \\
\text { Surface (MSL) }\end{array}$ \\
\hline $\mathrm{GW}-193$ & $12 / 18 / 93$ & $18.4 \mathrm{ft}$ & $934.00 \mathrm{ft}$ & $8.71 \mathrm{ft}$ & $925.29 \mathrm{ft}$ \\
$\mathrm{GW}-657$ & $12 / 18 / 93$ & $17.1 \mathrm{ft}$ & $930.53 \mathrm{ft}$ & $6.96 \mathrm{ft}$ & $923.57 \mathrm{ft}$ \\
$\mathrm{GW}-707$ & $12 / 18 / 93$ & $26.0 \mathrm{ft}$ & $930.91 \mathrm{ft}$ & $6.22 \mathrm{ft}$ & $924.69 \mathrm{ft}$ \\
$\mathrm{GW}-708$ & $12 / 18 / 93$ & $13.9 \mathrm{ft}$ & $930.87 \mathrm{ft}$ & $4.53 \mathrm{ft}$ & $926.34 \mathrm{ft}$ \\
$\mathrm{GW}-808$ & $12 / 18 / 93$ & $40.4 \mathrm{ft}$ & $930.75 \mathrm{ft}$ & $8.05 \mathrm{ft}$ & $922.70 \mathrm{ft}$ \\
$\mathrm{GW}-809$ & $12 / 18 / 93$ & $40.0 \mathrm{ft}$ & $931.04 \mathrm{ft}$ & $8.31 \mathrm{ft}$ & $922.73 \mathrm{ft}$ \\
$\mathrm{GW}-810$ & $12 / 18 / 93$ & $26.8 \mathrm{ft}$ & $931.44 \mathrm{ft}$ & $8.67 \mathrm{ft}$ & $922.77 \mathrm{ft}$ \\
\hline
\end{tabular}

1BGL - Below Ground Level

${ }^{2}$ MSL - Mean Sea Level

${ }^{3}$ BTOC - Below Top of Casing 


\section{DISTRIBUTION}

HEALTH, SAFETY, ENVIRONMENT AND ACCOUNTABILITY

ORGANIZATION

D.E. Bohrman (2)

L.L. Cunningham/E.M. Ingram

L.W. McMahon

File - EMD - RC

MECHANICAL OPERATIONS

ORGANIZATION
A.A. Barnes
ENVIRONMENTAL COMPLIANCE
ORGANIZATION

S.H. Welch

TENNESSEE DEPARTMENT OF

ENVIRONMENT AND

CONSERVATION

C. Head

E.C. Leming/J.D. Harless

\section{U.S DEPARTMENT OF ENERGY}

E M. Atkins

R.J. Spence/W.G. McMillan

S.R. Lankford

A.K. Lee/DOE-OSTI (2)

Y-12 Central Files 


\section{Appendix A}

\section{Monitoring Well Installation and Development Reports}




\section{A.1 GW-808}


Y-12 PLANT GROUNDWATER PROTECTION PROGRAM

WELL LOG
WELL NO. GW-808

FACILITY ID 0-010117 BUILDING 9201-1

PAGE 1 of 2

DATE: START:

FINISH: $\quad 7-23-93$

DRILLING METHOD: Air Rotary

LOGGED BY: S.L. Abston - SAIC

DRILL: Ingersoll- Rand T4W

NOTES: UST, PVC, screened well monitoring water zone in fracture of the Maynardville formation.

\begin{tabular}{|c|c|c|c|}
\hline \multicolumn{2}{|c|}{ DEPTH $(\mathrm{ft})$} & \multirow{2}{*}{$\begin{array}{c}\text { SAMPLE } \\
\text { (NO. \& INTERVAL) }\end{array}$} & \multirow{2}{*}{ SOIL/BEDROCK DESCRIPTION } \\
\hline FROM & TO & & \\
\hline 0.0 & 0.3 & & Asphalt \\
\hline \multirow[t]{9}{*}{0.3} & 6.0 & Beta + gamma = & Moderate brown (5YR $4 / 4$ ) clay with medium light gray to black \\
\hline & & $60 \mathrm{cpm}$ (background & (N6-N2) fragments of chert and limestone. Weathered bedrock \\
\hline & & $=60 \mathrm{cpm}) ;$ Organic & (TOWR) at $4.0 \mathrm{ft}$ BGS \\
\hline & & vapor (breathing & \\
\hline & & $z o n \theta)=0.2 \mathrm{ppm}$ & \\
\hline & & (background $=0.4$ & \\
\hline & & ppm); Alpha $=0.0$ & \\
\hline & & cpm (background = & \\
\hline & & $30 \mathrm{cpm})$ & \\
\hline \multirow[t]{4}{*}{6.0} & 10.0 & Beta + gamma $=50$ & Medium light gray to medium gray (N6-N5) limestone (microcrys- \\
\hline & & cpm. Organic vapor & talline) with $\neq 40 \%$ having microcalcite coatings. Fresh bedrock \\
\hline & & (breathing zone) $=0$ & (TOFR) at $6.2 \mathrm{ft}$ BGS. \\
\hline & & ppm; Alpha $=0 \mathrm{cpm}$ & \\
\hline \multirow[t]{4}{*}{10.0} & 25.0 & Beta + gamma $=50$ & Medium light gray to medium gray (N5-N6) microcrystalline \\
\hline & & cpm. Organic vapor & limestone. \\
\hline & & (breathing zone) $=0$ & \\
\hline & & ppm; Alpha $=0 \mathrm{cpm}$ & \\
\hline & & & \\
\hline & & & \\
\hline
\end{tabular}


Y-12 PLANT GROUNDWATER PROTECTION PROGRAM

WELL LOG - continued
WELL NO. GW-808

FACILITY ID 0-010 17 BUILDING 9201-1

PAGE 2 of 2

\begin{tabular}{|c|c|c|c|}
\hline \multicolumn{2}{|c|}{ DEPTH (ft) } & \multirow{2}{*}{$\begin{array}{c}\text { SAMPLE } \\
\text { (NO. \& INTERVAL) }\end{array}$} & \multirow{2}{*}{ SOILBEDROCK DESCRIPTION } \\
\hline FROM & TO & & \\
\hline \multirow[t]{4}{*}{25} & 31.4 & Beta + Gamma $=50$ & Gray (N4) microcrystalline limestone (95\%) with $5 \%$ light gray (N7) \\
\hline & & cpm;Organic Vapor & limestone. \\
\hline & & (breathing zone $=0$ & \\
\hline & & ppm; Alpha $=0 \mathrm{cpm}$ & \\
\hline & & & \\
\hline \multirow[t]{16}{*}{31.4} & 40.0 & & Medium dark gray (N4) microcrystalline limestone with $5 \%$ light \\
\hline & & & gray (N7) limestone: Light brown 5YR 5/6 weather staining present \\
\hline & & & on some fragments. \\
\hline & & & \\
\hline & & & Total depth $40.4 \mathrm{ft}$ BGS. \\
\hline & & & \\
\hline & & & SUBSURFACE DATA BASE SUMMARY* \\
\hline & & & \\
\hline & & & Rock formation(s): CON: Maynardville \\
\hline & & & Aquifer: B. \\
\hline & & & Fractures, Cavities, Waterbreaks: fracture $33.5 \mathrm{ft}(\mathrm{MW})$. \\
\hline & & & \\
\hline & & & "Refer to: Updated Subsurface Data Base for Bear Creek Valley, \\
\hline & & & Chestnut Ridge, and parts of Bethel Valley on the U.S. Department \\
\hline & & & of Energy Oak Ridge Resenvation, Y/TS-881, for data base expla- \\
\hline & & & nation. \\
\hline & & & \\
\hline & & & \\
\hline & & & \\
\hline & & & \\
\hline & & & \\
\hline & & & \\
\hline & & & \\
\hline & & & \\
\hline & & & \\
\hline & & & \\
\hline & & & \\
\hline
\end{tabular}


FACILITY ID

Y-12 PLANT GROUNDWATER PROTECTION PROGRAM

\section{BUILDING 9201.}

WELL NO. GW-808

\section{WELL INSTALLATION DIAGRAM}

LOGGED BY: S.L. Abston - SAIC

DRILUNG COMPANY: Highland Drilling Co.

DRILLING DATES

DRILLER: Hubert HallRandy Phillips HELPER

STARTED: $\quad 7-21-93$

FINISHED: $\quad 7.23 .93$

12.0 IN. DLA. STEEL MANHOLE COVER

PAVEMENT SURFACE

FLUSH MOUNTED WTHH PAVEMENT

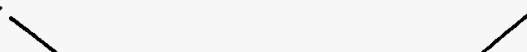

105/8IN. DLA. BOREHOLE FROM 0.0 TO 40.4 FT

TOP OF WEATHERED BEDROCK $4.0 \mathrm{FT}$ TOP OF FRESH BEDROCK 6.2 FT

NOTE:

ALL DEPTHS ARE MEASURED FROM GROUND SURFACE UNLESS OTHERWISE NOTED

HOLE CLEANED OUT TO 40.4 FT

DRILLED DEPTH OF BOREHOLE 40.4FT

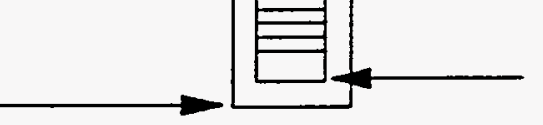

$41 / 2$ IN. OD PVC CAP

36.4 TO $36.9 \mathrm{FT}$

GROUT SEAL 2.8 TO

14.0 FT

$41 / 2$ IN. OD, 4.0 IN. ID, SCHEDULE 40 , PVC CASING

FROM 0.5 TO 26.4 FT

BENTONITE PELLET SEAL

14.0 TO $24.0 \mathrm{FT}$

SAND PACK 24.0 TO 40.4 FT

$41 / 2$ IN. OD, 4.0 IN. ID. PVC SLOTTED\#10 slot

OPENINGS, SCREEN 26.4 TO

$36.4 \mathrm{FT}$

NOT TO SCALE 


\section{MONITORING WELL DEVELOPMENT PROGRESS}

LOCATION: Building 9201-1

ONE WELL VOLUME: 19.0

GALLONS

WELI INSTALLLATION COMPLETION DATE:

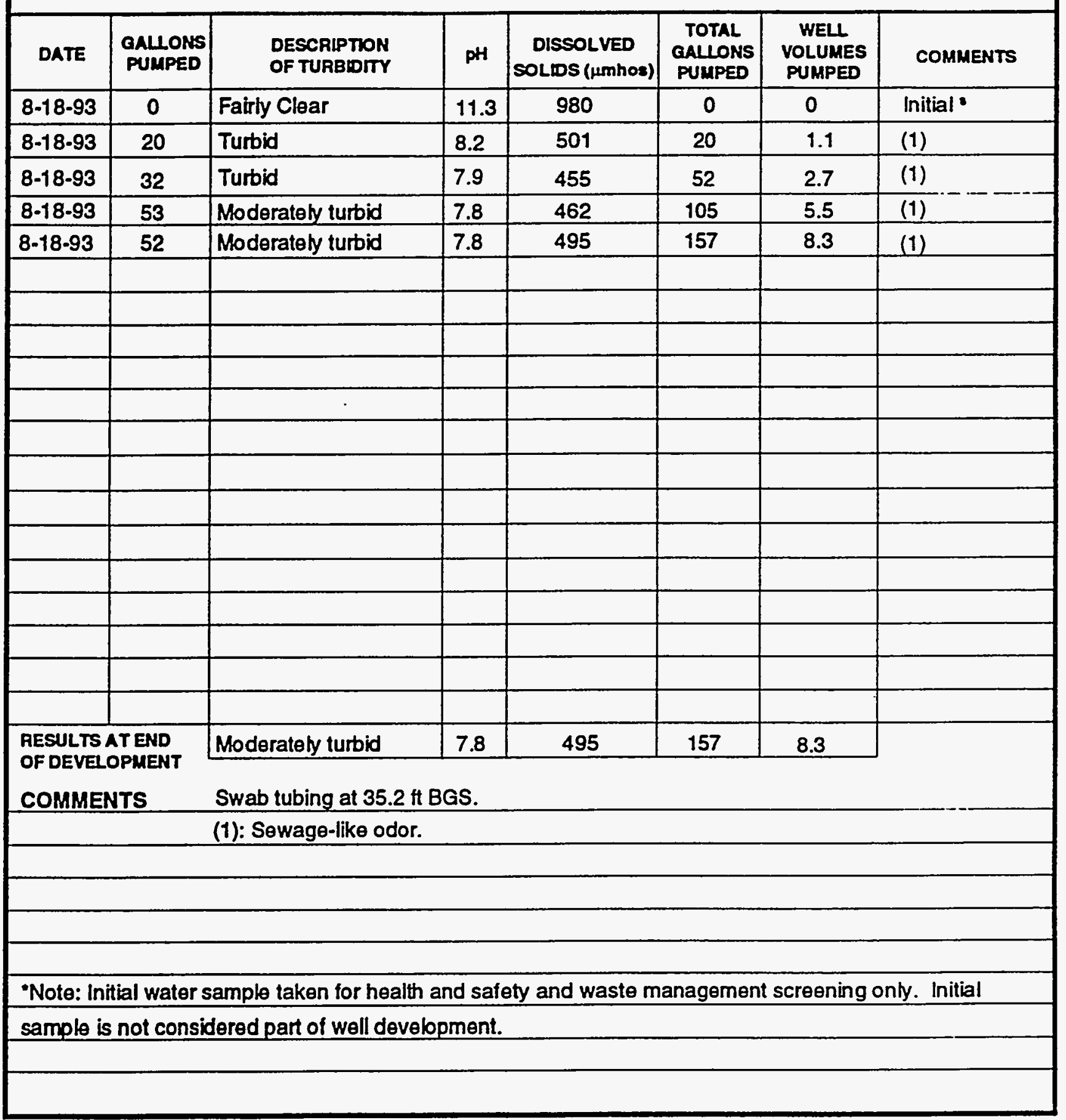


Y-12 PLANT GROUNDWATER PROTECTION PROGRAM

\section{MONITORING WELL DEVELOPMENT SUMMARY}

METHOD OF DEVELOPMENT: Swab

DEVELOPMENT OBSERVED BY: Timothy Cotfey - SAIC

ONE WELL VOLUME: 19.0 GALLONS

TOTAL GALLONS PUMPED:

157 TOTAL WELL VOLUMES PUMPED:

8.3

INITIAL PH: 8.2 FINAL pH: 7.8

INITIAL SPECIFIC CONDUCTANCE: $501 \mu \mathrm{mhos} / \mathrm{cm}$ FINAL: $495 \mu \mathrm{mhos} / \mathrm{cm}$ DEVELOPMENT DATE: START: 8-18-93

FINISH: 8-18-93

DAT DAT
$18-93$

DESCRIPTION OF FINAL TURBIDITY:

FINAL MEASURED TURBIDITY:

WELL APPROVED BY:

ODOR OF WATER:

Faint sowage-like ador. Moderately Turbid Not Analyzed
WATER DISCHARGED TO: $\square$ STORM SEWERS $\square$ DRUMS
$\square$ GROUND SURFACE
$\square$ TANK TRUCK
$\otimes$ STORAGE TANKS
$\square$ OTHER Turbid Steven B. Jones - HSEA

WELL NO. GW-808 FACILITY ID $00101011=$ BUILDING 9201-1

INITIAL PRE-DEVELOPMENT

WATER DEPTH:

DEVELOPMENT OBSERVATIONS: Well exhibits excellent recharge as evidenced by inability to draw water level down appreciably during development sessions. Development water cleared only slightly. Well development of $\mathrm{GW}-808$ drew water level in $\mathrm{GW}-809$ down $2.8 \mathrm{ft}$.

OBSERVER SIGNATURE:

DATE: 
A.2 GW-809

94-008MS/010794 


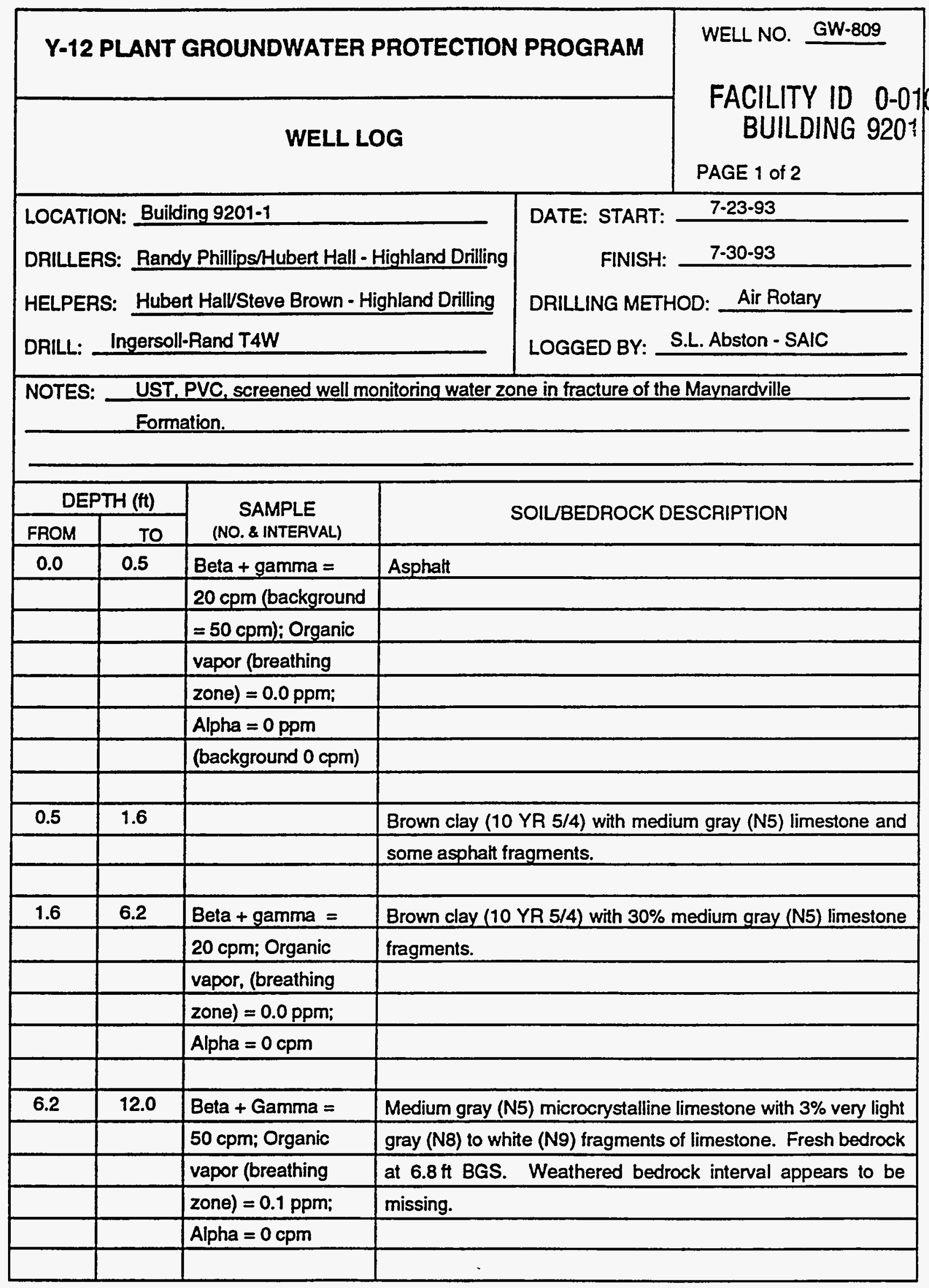


Y-12 PLANT GROUNDWATER PROTECTION PROGRAM

\section{WELL LOG - continued}

WELL NO. GW-809

FACILITY ID $0-010117$ BUILDING 9201-1

PAGE 2 of 2

\begin{tabular}{|c|c|c|c|}
\hline \multicolumn{2}{|c|}{ DEPTH $(\mathrm{ft})$} & \multirow{2}{*}{$\begin{array}{c}\text { SAMPLE } \\
\text { (NO. \& INTERVAL) }\end{array}$} & \multirow{2}{*}{ SOILBEDROCK DESCRIPTION } \\
\hline FROM & TO & & \\
\hline \multirow[t]{4}{*}{12.0} & 32.0 & Beta + Gamma $=40$ & Medium gray (N5) microcrystalline limestone with $3 \%$ very light \\
\hline & & cpm; Organic vapor & gray (N8) to white (N9) fragments of limestone. Fragments are \\
\hline & & (breathing zone) $=0.2$ & smaller in size. \\
\hline & & ppm; Alpha $=10 \mathrm{cpm}$ & \\
\hline \multirow[t]{4}{*}{32.0} & 35.5 & Beta + Gamma $=40$ & Medium gray microcrystalline limestone with very light gray (N8) \\
\hline & & cpm; Organic vapor & to white (N9) calcite fragments with brown weather staining on \\
\hline & & (breathing zone) $=0.2$ & larger fragments. Fracture at $34.0 \mathrm{ft}$ BGS. \\
\hline & & ppm; Alpha $=10 \mathrm{cpm}$ & \\
\hline \multirow[t]{4}{*}{35.5} & 40.0 & Beta + Gamma $=40$ & Medium gray (N5) microcrystalline limestone with very light gray \\
\hline & & cpm; Organic vapor & (N8) to white (N9) calcite fragments with very little brown weather \\
\hline & & (breathing zone) $=0.0$ & staining. \\
\hline & & ppm; Alpha $=0 \mathrm{cpm}$ & \\
\hline & & & \\
\hline & & & \\
\hline & & & Total depth $=40 \mathrm{ft}$ BGS. \\
\hline & & & \\
\hline & & & SUBSURFACE DATA BASE SUMMARY` \\
\hline & & & Rock Formation CON: Maynardville \\
\hline & & & Aquifer: B \\
\hline & & & Fracture, Cavities, Waterbreaks: fracture: $34.0 \mathrm{ft}(\mathrm{MW})$. \\
\hline & & & \\
\hline & & & Refer to: Updated Subsurface Data Base for Bear Creek Valley, \\
\hline & & & Chestnut Ridge, and parts of Bethel Valley on the U.S. Depart- \\
\hline & & & ment of Energy Oak Ridge Reservation, $Y / T S-881$, for data base \\
\hline & & & explanation. \\
\hline & & & \\
\hline & & & \\
\hline & & & \\
\hline & & & \\
\hline
\end{tabular}




\section{Y-12 PLANT GROUNDWATER PROTECTION PROGRAM}

\section{WELL INSTALLATION DIAGRAM}

WELL NO. GW-809

LOGGED BY: S.L. Abston - SAIC

DRILLING DATES

DRILLING COMPANY: Highland Drilling Co.

DRILLER: Randy Phillips HELPER: Steve Brown

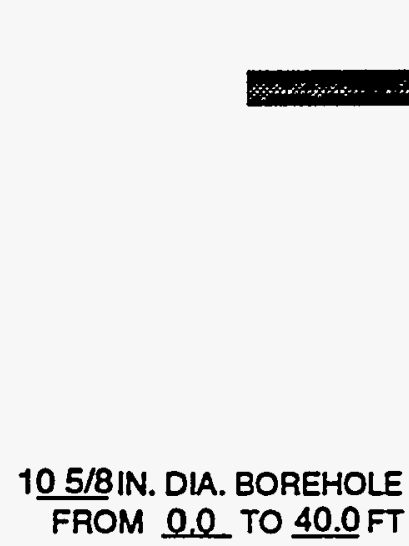

TOP OF WEATHERED BEDROCK $\underline{6.8} F T$ TOP OF FAESH BEDROCK 6.8 FT CENTRALIZER AT $\underline{9.0}$ FT

NOTE:

ALL DEPTHS ARE MEASURED FROM GROUND SURFACE UNLESS OTHERWISE NOTED
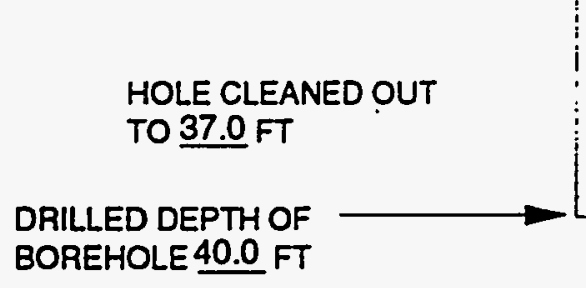
BOREHOLE $\underline{40.0}$ FT
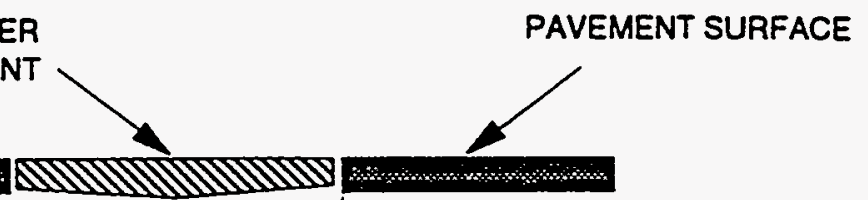
LOCKING CAP GROUT SEAL 3.5 TO $17.2 \mathrm{FT}$

$-41 / 2$ IN. OD, 4.0 IN. ID, SCHEDULE $\overline{40}$. PVC CASING FROM SURFACE TO 26.0 FT BENTONITE PELLET SEAL $\underline{17.2}$ TO $\underline{23.9} \mathrm{FT}$ SAND PACK 23.9 TO 37.0 FT $41 / 2$ IN. OD, 4.0 IN. ID, PVC SLOTTED\#10 slot OPENINGS, SCREEN 26.0 TO 36.0 FT

$41 / 2$ IN. OD PVC CAP 36.0 TO36.5 FT

NOT TO SCALE 


\section{MONITORING WELL DEVELOPMENT PROGRESS}

LOCATION: Building 9201-1_ ONE WELL VOLUME: 17.9 GALLONS

WELI INSTALLATION COMPLETION DATE: $\quad 7 \cdot 30-93$

\begin{tabular}{|c|c|c|c|c|c|c|c|}
\hline DATE & $\begin{array}{l}\text { GALLONS } \\
\text { PULPED }\end{array}$ & $\begin{array}{l}\text { DESCRIPTION } \\
\text { OF TURBDITY }\end{array}$ & pH & \begin{tabular}{|c|}
$\begin{array}{c}\text { DISSOLVED } \\
\text { SOLDS ( } \mu \text { mhos) }\end{array}$ \\
\end{tabular} & $\begin{array}{c}\text { TOTAL } \\
\text { CALLONS } \\
\text { PUMPED } \\
\end{array}$ & $\begin{array}{c}\text { WELL } \\
\text { VOLUMES } \\
\text { PUMPED }\end{array}$ & COMMENTS \\
\hline 8-16-93 & 0 & Clear & 12.1 & 8200 & 0 & 0 & Initial ${ }^{\circ}$ \\
\hline $8-16-93$ & 15 & Turbid (silty) & 12.2 & 4450 & 15 & 0.8 & (1) \\
\hline $8-16-93$ & 40 & Turbid (silty) & 11.4 & 795 & 55 & 3.1 & (1) \\
\hline $8-16-93$ & 55 & Turbid & 9.9 & 409 & 110 & 6.1 & (2) \\
\hline $8 \cdot 16.93$ & 55 & Turbid & 9.4 & 471 & 165 & 9.2 & (3) \\
\hline $8-16-93$ & 55 & Moderately turbid & 8.9 & 412 & 220 & 12.3 & (3) \\
\hline $8-17-93$ & 20 & Moderately turbid & 8.4 & 460 & 240 & 13.4 & (2) \\
\hline $8-17-93$ & 32 & Moderately turid & 7.7 & 495 & 272 & 15.2 & (2) \\
\hline $8-17-93$ & 20 & Moderately turbid & 7.5 & 500 & 292 & 16.3 & (2) faint \\
\hline $8-17-93$ & 32 & Slightly turbid & 7.5 & 500 & 324 & 18.1 & (2) faint \\
\hline & & & & & & & \\
\hline & & & & & & & \\
\hline & & & & & & & \\
\hline & & & & & & & \\
\hline & & & & & & & \\
\hline & & & & & & & \\
\hline & & & & & & & \\
\hline & & & & & & & \\
\hline & & & & & & & \\
\hline \multicolumn{2}{|c|}{$\begin{array}{l}\text { RESULTS AT END } \\
\text { OF DEVELOPMENT }\end{array}$} & Slightly Turbid & 7.5 & 500 & 324 & 18.1 & \\
\hline \multicolumn{2}{|c|}{ COMMENTS } & \multicolumn{6}{|c|}{ Swab tubing to $35.91 \mathrm{ft}$ BGS. } \\
\hline \multicolumn{8}{|c|}{ (1): Water has cement odor. } \\
\hline \multicolumn{8}{|c|}{ (2): Sowage-like oder. } \\
\hline & & (3): Petroliferous od & & & & & \\
\hline
\end{tabular}

-Note: Initial sample for health and safety and waste management screening only. Not included in well development summary. 


\section{Y-12 PLANT GROUNDWATER PROTECTION PROGRAM}

\section{MONITORING WELL DEVELOPMENT SUMMARY}

METHOD OF DEVELLOPMENT: SWab

DEVELOPMENT OBSERVED BY: Timothy Coffey - SAIC

ONE WELL VOLUME:

17.9 GALLONS

TOTAL GALLONS PUMPED: TOTAL WELL VOLUMES PUMPED:

18.1

INITIAL PH: 12.2

FINAL PH:

7.5

INITIAL SPECIFIC CONDUCTANCE: $4450 \mu \mathrm{mhos} / \mathrm{cm}$ FINAL: $500 \mu \mathrm{mhos} / \mathrm{cm}$

DESCRIPTION OF INITIAL TURBIDITY: Turbid (silty)

DESCRIPTION OF FINAL TURBIDITY: Slightly Turbid

FINAL MEASURED TURBIDITY: Not Analyzed

WELL APPROVED BY:

Steven B. Jones - HSEA

ODOR OF WATER:

Observed cement, sewage-like odor, and petroliferous odors.

WATER DISCHARGED TO:

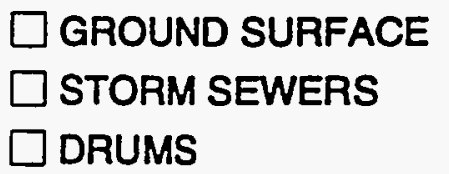

$\square$ TANK TRUCK

囚 STORAGE TANKS

$\square$ OTHER

INITIAL PRE-DEVELOPMENT

WATER DEPTH: 9.2 $\mathrm{ft}$ BGS on 8-16-93

DEVELOPMENT OBSERVATIONS: Well exhibits excellent recharge as evidenced by the inability to draw water level down appreciably during development sessions. Unable to clear the water entirely. Swabbing of GW-809 drew water level in GW-808 down $1.5 \mathrm{ft}$ on 8-16-93 and $2.8 \mathrm{ft}$ on 8-17-93.

OBSERVER SIGNATURE:

DATE: $\quad$ 8-17-93 


\section{A.3 GW-810}

94-008MS/010794 


\section{WELL LOG}

WELL NO. GW-810

FACILITY ID 0-010117 BUILDING 9201-

PAGE 1 of 2

LOCATION: Building 9201-1

DRILLERS: Hubert Hall - Highland Drilling Co.

HELPERS: David Hewitt - Highland Drilling Co.

DRILL: Ingersoll-Rand T4W

NOTES: UST, PVC, screened well monitoring water zone in fracture of the Maynaroville Formation.

\begin{tabular}{|c|c|c|c|}
\hline \multicolumn{2}{|c|}{ DEPTH $(\mathrm{ft})$} & \multirow{2}{*}{$\begin{array}{c}\text { SAMPLE } \\
\text { (NO. \& INTERVAL) } \\
\end{array}$} & \multirow{2}{*}{ SOIL/BEDROCK DESCRIPTION } \\
\hline FROM & TO & & \\
\hline \multirow[t]{8}{*}{0.0} & 0.5 & Beta + gamma = & Asphalt \\
\hline & & $30 \mathrm{ppm}$ (background $=$ & \\
\hline & & $40 \mathrm{cpm})$, Organic & \\
\hline & & vapor, breathing zone & \\
\hline & & $=1 \mathrm{ppm}$ (background & \\
\hline & & $=0.8 \mathrm{ppm}) ;$ Alpha $=$ & \\
\hline & & 0 ppm (background = & \\
\hline & & $0 \mathrm{cpm})$ & \\
\hline \multirow[t]{4}{*}{0.5} & 3.5 & Beta + gamma $=40$ & Moderate brown (5YR $3 / 4$ ) clay with very small medium gray (N6) \\
\hline & & cpm; Organic vapor. & limestone fragments. Competent bedrock @ $3.5 \mathrm{ft}$ BGS. Weath- \\
\hline & & (breathing zone); $=1.4$ & ered bedrock interval is apparently missing. \\
\hline & & ppm; Alpha $=0 \mathrm{cpm}$ & \\
\hline \multirow[t]{4}{*}{3.5} & 6.5 & Beta + Gamma $=40$ & Medium gray (N5) small to medium $1.5 \mathrm{~mm}$ microcrystalline \\
\hline & & cpm; Organic vapor & limestone fragments with moderate yellowish brown (10YR 5N) \\
\hline & & (breathing zone) $=1.4$ & weather staining. \\
\hline & & ppm; Alpha $=0 \mathrm{cpm}$ & \\
\hline \multirow[t]{4}{*}{6.5} & 19.5 & Beta + Gamma = 45 & Medium gray N5 with some areas of light gray to white (N8 to N9) \\
\hline & & cpm; Organic vapor & microcrystalline limestone. \\
\hline & & (breathing zone) $=1.2$ & \\
\hline & & ppm; Alpha $=0 \mathrm{cpm}$ & \\
\hline
\end{tabular}




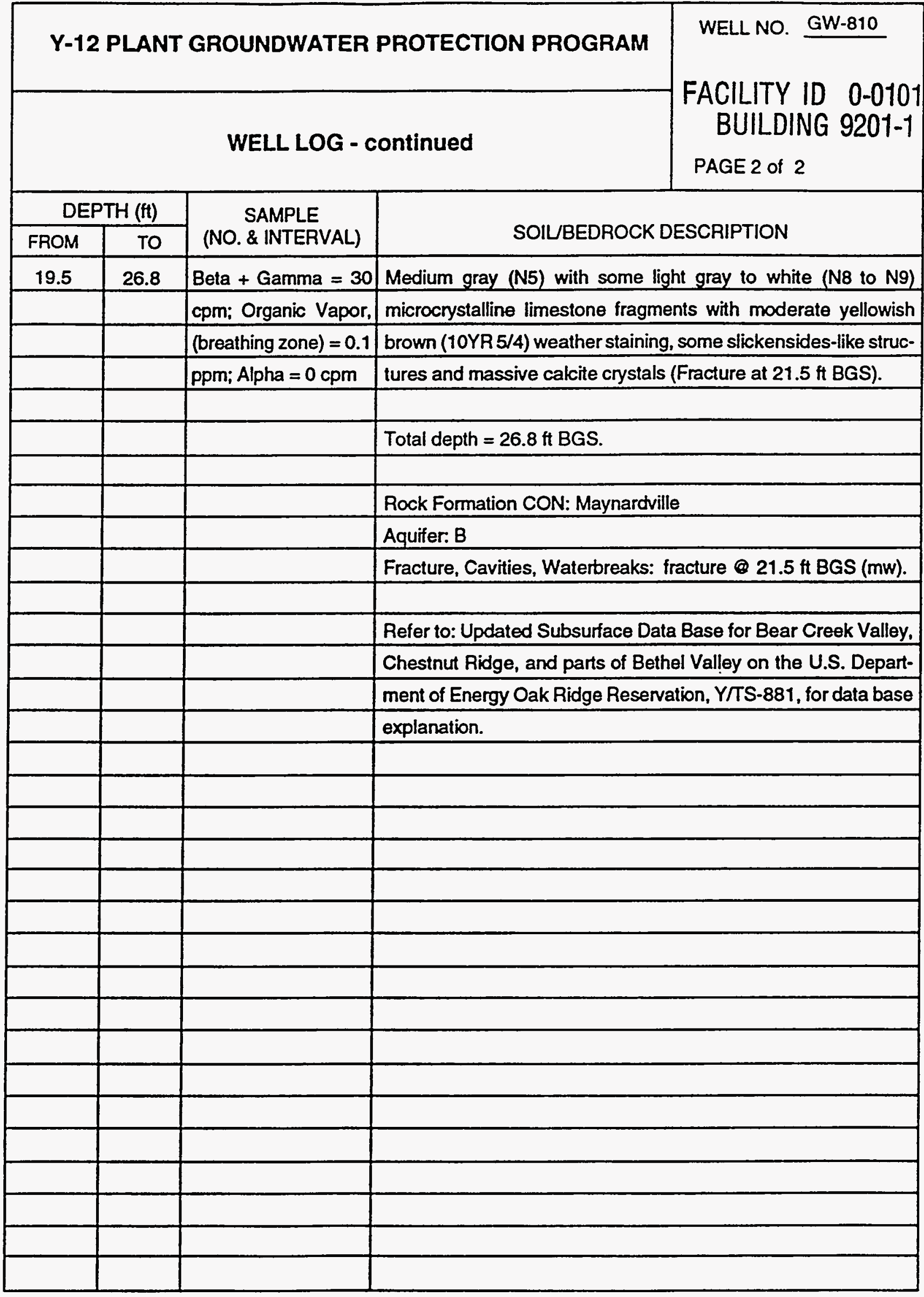




\section{WELL INSTALLATION DIAGRAM}

LOGGED BY: S.L. Abston - SAIC

DRILLING COMPANY: Highland Drilling Co.

DRILLER: Hubert Hall HELPER: David Howitt

DRILLING DATES

STARTED: $7-28-93$

FINISHED: $\quad 7.30-93$

\subsection{IN. DIA. STEEL MAN-HOLE COVER PAVEMENT SURFACE}

10 5/8IN. DIA. BOREHOLE FROM 0 TO26.8 FT

TOP OF WEATHERED BEDROCK-NA-FT

TOP OF FRESH BEDROCK $\underline{3.5}$ FT

NOTE:

ALL DEPTHS ARE MEASURED FROM GROUND SURFACE UNLESS OTHERWISE NOTED

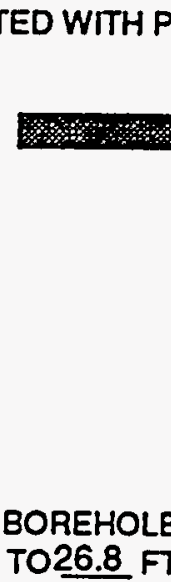




\section{MONITORING WELL DEVELOPMENT PROGRESS}

LOCATION: Building 9201-1

ONE WELL VOLUME: 11.2 GALLONS

WEL INSTALLATION COMPLETION DATE:

\begin{tabular}{|c|c|c|c|c|c|c|c|}
\hline DATE & \begin{tabular}{|c|} 
GALLONS \\
PULAPED
\end{tabular} & $\begin{array}{l}\text { DESCAIPTION } \\
\text { OF TURBDITY }\end{array}$ & pH & $\begin{array}{c}\text { DISSOLVED } \\
\text { SOLLDS (umhO:) }\end{array}$ & $\begin{array}{c}\text { TOTAL } \\
\text { GALLONS } \\
\text { PUMPEDD } \\
\end{array}$ & $\begin{array}{c}\text { WELL } \\
\text { VOLUMES } \\
\text { PUMPED }\end{array}$ & COMMENTS \\
\hline $8-16-93$ & 0 & Clear & 10.8 & 920 & 0 & 0 & Initial ${ }^{*}$ \\
\hline $8-16-93$ & 20 & Turbid & 7.7 & 498 & 20 & 1.8 & \\
\hline $8-16.93$ & 17 & Moderately turbid & 7.7 & 500 & 37 & 3.3 & (1) \\
\hline $8-16-93$ & 16 & Moderately turbid & 7.5 & 501 & 53 & 4.7 & (1) \\
\hline $8-16-93$ & 15 & Slightly turbid & 7.5 & 505 & 68 & 6.1 & (1) (2) \\
\hline $8-16-93$ & 25 & Slightly turbid & 7.7 & 510 & 93 & 8.3 & (1) (2) (3) \\
\hline & & & & & & & \\
\hline & & & & & & & \\
\hline & & & & & & & \\
\hline & & & & & & & \\
\hline & & & & & & & \\
\hline & & & & & & & \\
\hline & & & & & & & \\
\hline & & & & & & & \\
\hline & & & & & & & \\
\hline & & & & & & & \\
\hline & & & & & & & \\
\hline & & & & & & & \\
\hline & & & & & & & \\
\hline \multirow{2}{*}{\multicolumn{2}{|c|}{$\begin{array}{l}\text { RESULTS AT END } \\
\text { OF DEVELOPMENT } \\
\text { COMMENTS } \\
\end{array}$}} & Slightly Turbid & 7.7 & 510 & 93 & 8.3 & \\
\hline & & \multicolumn{6}{|c|}{ Swab tubing to $26.1 \mathrm{ft}$ BGS. } \\
\hline \multicolumn{8}{|c|}{ (1): Sewage odor. } \\
\hline \multicolumn{8}{|c|}{ (2): Water also has a rotten-egg odor. } \\
\hline
\end{tabular}

-Note: Initial sample for health and safety and waste management screening only. Not included in well devolopment summary. 


\section{MONITORING WELL DEVELOPMENT SUMMARY}

METHOD OF DEVELOPMENT: Swab

DEVELOPMENT OBSERVED BY: Timothy Coffey - SAIC

ONE WELL VOLUME: 11.2 TOTAL GALLONS PUMPED: 93 7.7

INITIAL pH: FINAL pH: $498 \mu \mathrm{mhos} / \mathrm{cm}$ FINAL: $510 \mu \mathrm{mhos} / \mathrm{cm}$

INITIAL SPECIFIC CONDUCTANCE: GALLONS
DEVELOPMENT DATE:

START: $8-16-93$

FINISH: $8-16-93$
8.3

MPE: 7.7

DESCRIPTION OF INITIAL TURBIDITY: $\quad$ TUMID

DESCRIPTION OF FINAL TURBIDITY: Slightly Turbid

FINAL MEASURED TURBIDITY: Not Analyzed

WELL APPROVED BY:

Steven B. Jones - HSEA

ODOR OF WATER: Observed a sewage-like odor and rotten-egg odor.

WATER DISCHARGED TO: $\square$ GROUND SURFACE $\square$ STORM SEWERS $\square$ DRUMS 


\section{Appendix B}

Laboratory Analytical Results for Baseline Groundwater Sampling 


\section{B.1 Groundwater Sample Analytical Results}


UNCLASSIFIED

OFFICIAL REPORT
FACILITY ID $00.01011^{-}$

BUILDING 9201-1
$1 / 29 / 9308: 00: 52$

\section{JBMITTER}

asterling, Samuel $D$

ITE SAMPLED: 11/02/93 15:39:00

ATE RECEIVED: $11 / 03 / 93$

AMPLER: $13303 / 29776$
Y-12 AMALYTICAL SERVICES ORGANIZATIOH
PAGE 1 OF 1

\section{PHAENTS: RESULTS HEEDED AS SOON AS POSSIBLE}

$\frac{\text { CUSTOMER 10 }}{A 11576} \frac{\text { REO NO }}{\text { A11576 }} \frac{\text { SAMPLE NO }}{\text { E933060045 }}$
LOCATIOH: GH-193 PROJECT COOE:
HTC STATUS 8601 APPROVED CHARGE \#: S2205F26 CASE : $\operatorname{NO3130}$
DATE COMPLETED: $11 / 29 / 93$

SAMPLE DESCRIPTION: GRAB

EST: GRO TPH Gasol ine Range Organics Including BTEX

REP MTH: PROC MTH: SW846 8020 PHASE:

OMMENTS: $E$ indicates that benzene exceeded calibration range

\begin{tabular}{|c|c|c|c|c|c|}
\hline AS HUMBER & DETERMINATIOH & or & RESULT & COHFIOENCE & UNIT \\
\hline & Gasol ine Range Organics & & 5500 & & ug/l \\
\hline 1432 & Benzene & & 1675E & & ug/l \\
\hline 00414 & Ethylbenzene & & 575 & & $u g / L$ \\
\hline 08883 & Toluene & & 235 & & ug/l \\
\hline 330207 & Xylene & & 353 & & $u g / \mathrm{l}$ \\
\hline
\end{tabular}

EST: VOABTEX VOA Analysis, BTEX Compounds (SW846 8260)

REP MTH: PROC HTH: SH846 8260 PHASE:

THIS TEST WAS CANCELLED
REPLICATE: 1

STATUS: APPROVED

FIHAL APPROVAL

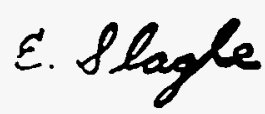




\section{UNCLASSIFIED}

OFFICIAL REPORT

Y-12 AHALYTICAL SERVICES ORGAHIZATION

\section{FACILITY ID 0-010117 BUILDING 9201-1}

PAGE 1 OF 1
/29/93 09:26:55

\section{BMITTER}

'sterling, samuel $D$

TE SAMPLED: 11/02/93 17:53:00

TE RECEIVED: $11 / 03 / 93$

MPLER: $13303 / 29776$

\section{ADDRESS}

BUILDING 9207 MS 8225

DATE NEEDED: $11 / 05 / 93$

DATE COMPLETED: $11 / 29 / 93$

SAMPLE DESCRIPTIOH: GRAB $\frac{\text { CUSTOMER ID }}{111577} \frac{\text { REQ NO }}{\text { A11577 }} \frac{\text { SAMPLE HO }}{\text { E933060046 }}$

LOCATION: GU-657

PROJECT COOE:
MTC STATUS

8601 APPROVED

CHARGE : S2205F26

CASE: 003130

FIKAL APPROVAL:

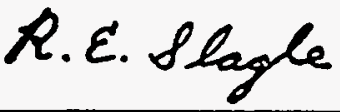

REPLICATE: 1

STATUS: APPROVED

TIME ANALYZED: 11/15/93 00:00:00 APPROVER: E021503 PROC MTH: SW\&46 8020 PHASE:

\begin{tabular}{crr} 
DI RESULT & CONFIDENCE & UNIT \\
\hline & $<100$ & $\mathrm{Ug} / \mathrm{L}$ \\
& $<1$ & $\mathrm{ug} / \mathrm{L}$ \\
& $<1$ & $\mathrm{ug} / \mathrm{L}$ \\
$<1$ & $\mathrm{ug} / \mathrm{L}$ \\
$<1$ & $\mathrm{ug} / \mathrm{L}$
\end{tabular}

REPLICATE: 1

STATUS: CAKCELLED

TIME AHALYZED:

THIS TEST WAS CAMCELLED 
UNCLASSIFIED

OFFICIAL REPORT
$/ 29 / 93 \quad 09: 27: 19$

\section{BMITTER}

sterling, Samuel $D$

TE SAMPLED: 11/02/93 17:10:00

TE RECEIVED: $11 / 03 / 93$

MPLER: $13303 / 29776$

ADORESS
BUILDING
$7: 10: 00$
Y-12 ANALYTICAL SERVICES ORGAHIZATION

\section{FACILITY ID 0-010117 \\ BUILDING 9201-1}

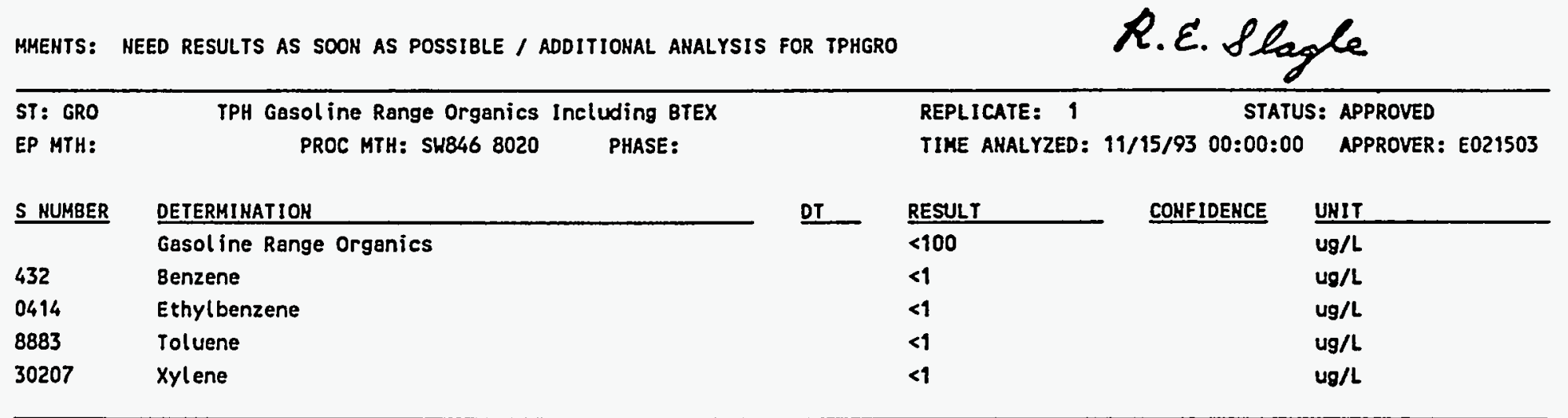

\begin{tabular}{llll}
\hline ST: VOABTEX & VOA AnalYSIS, BTEX COMPOUndS (SH846 8260) & REPLICATE: 1 STATUS: CAHCELLED \\
EP MTH: & PROC MTH: SH846 $8260 \quad$ PHASE: & TIME AHALYZED: &
\end{tabular}

PAGE 1 OF 1

\begin{tabular}{|c|c|c|c|c|}
\hline CUSTOMER ID & REQ NO & SAHPLE HO & MTC & STATUS \\
\hline A11579 & 111579 & E933060048 & 8601 & APPROVED \\
\hline $\begin{array}{l}\text { LOCATION: GH-708 } \\
\text { PROJECT COOE: }\end{array}$ & & & $\begin{array}{l}\text { CHARG } \\
\text { CASE: }\end{array}$ & $\begin{array}{l}y=52205 F 26 \\
03130\end{array}$ \\
\hline
\end{tabular}

FINAL APPROVAL: $\begin{array}{ll}\text { DATE NEEDED: } 11 / 05 / 93 & \text { LOCATION: GW-708 } \\ \text { DATE COMPLETED: } 11 / 29 / 93 & \text { PROJECT COOE: }\end{array}$

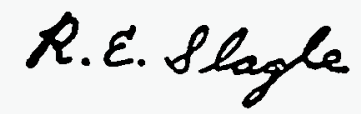

STATUS: APPROVED

REPLICATE:

RESULT

$<1$

$<1$

$<1$

REPLICATE:
SAMPLE DESCRIPTION: GRAB

ADDRESS
BUILOING 9207 MS 8225
$\begin{aligned} & 17: 10: 00 \quad \text { DATE NEEDED: } 11 / 05 / 93 \\ & \text { DATE COMPLETED: } 11 / 29 / 93 \\ & \text { SAMPLE DESCRIPIION: GRAB }\end{aligned}$
AS SOON AS POSSIBLE / ADDITIONAL ANAL
Gasoline Range Organics Including BTEX
PROC MTH: SH846 8020 PHASE:




\section{UNCLASSIFIED}

OFFICIAL REPORT

\section{FACILITY ID $\quad 0-010117$ BUILDING 9201-1}

3MITTER
$\begin{array}{ll}\text { 3terling, Sanuel D } & \text { ADDRESS } \\ \text { IE SAMPLED: } 11 / 02 / 93 \text { 15:08:00 } & \text { DATE HEEDED: } 11 / 05 / 93 \\ \text { IE RECEIVED: } 11 / 03 / 93 & \text { DATE COMPLETED: } 191 / 29 / 93 \\ \text { APLER: } 13303 / 29776 & \text { SAMPLE DESCRIPTIOH: GRAB }\end{array}$

MMENTS: HEEO AS SOOM AS POSSIBLE / ADDITIONAL ANALYSIS FOR TPHGRO

$\begin{array}{lllll}\text { CUSTOMER ID } & \frac{\text { REO NO }}{\text { A11580 }} & \frac{\text { SAMPLE NO }}{\text { E933060049 }} & \frac{\text { MTC }}{8601} \frac{\text { STATUS }}{\text { APPROVED }} \\ \begin{array}{l}\text { A11580 } \\ \text { LOCATION: GH-808 }\end{array} & & \begin{array}{l}\text { CHARGE : S2205F26 } \\ \text { PROJECT COOE: }\end{array} & & \text { CASE: U03130 }\end{array}$

FIHAL APPROVAL:

\begin{tabular}{|c|c|c|c|c|c|}
\hline $\begin{array}{l}\text { ST: GRO } \\
\text { EP MTH: }\end{array}$ & $\begin{array}{c}\text { TPH Gasoline Range Organics Including BTEX } \\
\text { PROC MTH: SH846 } 8020 \quad \text { PHASE: }\end{array}$ & & $\begin{array}{l}\text { REPLICATE: } 1 \\
\text { TIME AKALYZED: }\end{array}$ & $\begin{array}{l}\text { STATUS } \\
15 / 9300: 00: 00\end{array}$ & $\begin{array}{l}\text { S: APPRÖVED } \\
\text { APPROVER: E021503 }\end{array}$ \\
\hline \multirow[t]{2}{*}{$S$ MUMBER } & DETERMINATIOH & DT & RESULT & COMFIDENCE & UHIT \\
\hline & Gasoline Range Organics & & 140 & & $u g / L$ \\
\hline 432 & Benzene & & $<1$ & & ug/L \\
\hline 0414 & Ethylbenzene & & 16 & & ug/L \\
\hline 3883 & Toluene & & $<1$ & & ug/L \\
\hline 30207 & Xylene & & 111 & & $\omega g / L$ \\
\hline ST: VOABTEX & VOA Analysis, BTEX Compounds (SW846 8260) & & REPLICATE: 1 & STATUS & S: CANCELLED \\
\hline EP MTH: & $\begin{array}{l}\text { PROC MTH: SH846 } 8260 \\
\text { THIS TEST WAS CANCELLED }\end{array}$ & & TIME AHALYZED: & & NPPROVER: \\
\hline
\end{tabular}


UNCLASSIFIED

OFFICIAL REPORT
Y-12 ANALYTICAL SERVICES ORGANIZATION

PAGE 1 OF 1

\section{FACILITY ID 0-010117 BUILDING 9201-1}

ADDRESS

BUILDIKG 9207 HS 8225

DATE NEEDED: 11/05/93

DATE COHPLETED: $11 / 29 / 93$

SAMPLE DESCRIPTION: GRAB
CUSTOMER 10 REQ NO SAMPLE NO A11581 $\quad$ A11581 E933060050 LOCATION: GH-809 PROJECT COOE:
MTC STATUS 8601 APPROVED CHARGE \#: S2205F26 CASE: UO3130

IE RECEIVED: 11/03/93

IPLER: $13303 / 29776$

FIHAL APPROVAL:

MMENTS: NEED RESULTS AS SOON AS POSSIBLE / ADDITIOHAL ANALYSIS FOR TPHGRO

iT: GRO TPH Gasol ine Range Organics Including BTEX

IP MTH: PROC MTH: SW846 8020 PHASE:

; HUMBER DETERMINATION

Gasol ine Range Organics

Benzene

Ethylbenzene

Toluene

xylene

3883

3020 $\underline{\text { or }}$

RES

$<100$

$<1$

2.6

$<1$

16
REPLICATE: 1

TIME AHALYZED: 11/15/95 00:00:00 APPROVER: E021503
VOA Analysis, BTEX Compounds (SW846 8260)

PROC HTH: SW846 8260 PHASE:

THIS TEST HAS CANCELLED

REPLICATE: 1

TIME AHALYZED:
CONFIDENCE UNIT

ug/L

ug/L

$u g / L$

$u g / L$

$u g / L$
iT: VOABTEX :P MTH: 


\section{UNCLASSIFIED}

OFFICIAL REPORT

\section{FACILITY ID $0-010117$ \\ BUILDING 9201-1}

\begin{tabular}{|c|c|c|}
\hline BMITTER & ADDRESS & \\
\hline sterling, Samuel 0 & BUILDING & 9207 MS 8225 \\
\hline TE SAMPLED: $11 / 02 / 93$ & $17: 22: 00$ & DATE HEEDED: $11 / 05 / 93$ \\
\hline TE RECEIVED: $11 / 03 / 93$ & & DATE COMPLETED: $19 / 29 / 93$ \\
\hline MPLER: $13303 / 29776$ & & SAMPLE DESCRIPTION: GRAB \\
\hline
\end{tabular}

\section{BMITTER}

MMENTS: NEED RESULTS AS SOON AS POSSIBLE / ADDITIONAL AHALYSIS FOR TPHGRO

ST: GRO TPH Gasol ine Range Organics Including BTEX
EP MTH: PROC MTH: SWB46 8020 PHASE:
MTC STATUS 8601 APPROVED CHARGE \#: S2205F26 CASE: U03130

FIMAL APPROVAL:

\begin{tabular}{|c|c|c|c|c|c|}
\hline S MUMBER & OETERMINATION & DT & RESULT & CONFIDENCE & UHIT \\
\hline & Gasoline Range Organics & & 190 & & $\overline{u g / L}$ \\
\hline 432 & Benzene & & 1.1 & & ug/L \\
\hline 0414 & Ethylbenzene & & 19 & & ug/L \\
\hline 8883 & Toluene & & 1.3 & & ug/L \\
\hline 30207 & Xylene & & 136 & & $u g / L$ \\
\hline
\end{tabular}

ST: VOABTEX EP MTH:

\author{
VOA Analysis, BTEX Compounds (SHB46 8260) \\ PROC MTH: SH846 8260 PHASE: \\ THIS TEST WAS CANCELLED
}

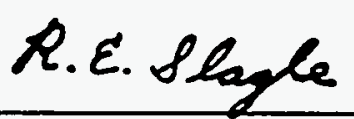

REPLICATE: 1 STATUS: APPROVED

TIME ANALYZED: 11/95/93 00:00:00 APPROVER: E021503

REPLICATE: 1

TIME AHALYZED:

STATUS: CANCELLED

APPROVER: 


\section{B.2 Quality Control Sample Analytical Results}


UNCLASSIFIED

OFFICIAL REPORT

\section{FACILITY ID 0-010117 BUILDING 9201-1}

\begin{tabular}{|c|c|c|c|c|c|c|c|}
\hline 3MITTER & ADDRES & & CUSTOMER ID & REO NO & SAMPLE NO & MTC & STATUS \\
\hline sterling, Samuel D & BUILDII & 9207 MS 8225 & 111583 & A11583 & $E 933060052$ & 8601 & APPROVED \\
\hline $\begin{array}{l}\text { IE SAMPLED: } 11 / 02 / 93 \\
\text { IE RECEIVED: } 11 / 03 / 93\end{array}$ & $3^{12: 35: 00}$ & $\begin{array}{l}\text { DATE KEEDED: } 11 / 16 / 93 \\
\text { DATE COMPLETED: } 11 / 29 / 93\end{array}$ & $\begin{array}{l}\text { LOCATIOH: TRIP } \\
\text { PROJECT COOE: }\end{array}$ & BLANK/UST & & $\begin{array}{l}\text { CHARE } \\
\text { CASE: }\end{array}$ & $\begin{array}{l}\text { : } 52205 F 26 \\
03130\end{array}$ \\
\hline APLER: $13303 / 29776$ & & SAMPLE DESCRIPTION: GRAB & & FIMAL APP & & & \\
\hline
\end{tabular}

ST: GRO TPH Gasoline Range Organics Including BTEX

IP MTH: $\quad$ PROC MTH: SWB46 8020 PHASE:

5 MUMBER DETERMINATIOH

Gasol ine Range Organics

Benzene

Ethylbenzene

Toluene

xylene
REPLICATE: 9

STATUS: APPROVED

TIME AKALYZED: 11/15/93 00:00:00

APPROVER: E021503

\begin{tabular}{|c|c|c|c|}
\hline DT & RESULT & CONFIDENCE & UNIT \\
\hline & $<100$ & & $u g / L$ \\
\hline & $<1$ & & ug/L \\
\hline & $<1$ & & ug/L \\
\hline & $<1$ & & ug/L \\
\hline & $<1$ & & ug/L \\
\hline
\end{tabular}

ST: VOA Volatile Organics by GC/MS (SWB46 8260)

EP MTH: PROC MTH: SW846 8260 PHASE:

THIS TEST WAS CAHCELLED
REPLICATE: 1

TIME AMALYZED:
STATUS: CANCELLED

APPROVER:

UNCLASSIFIED 


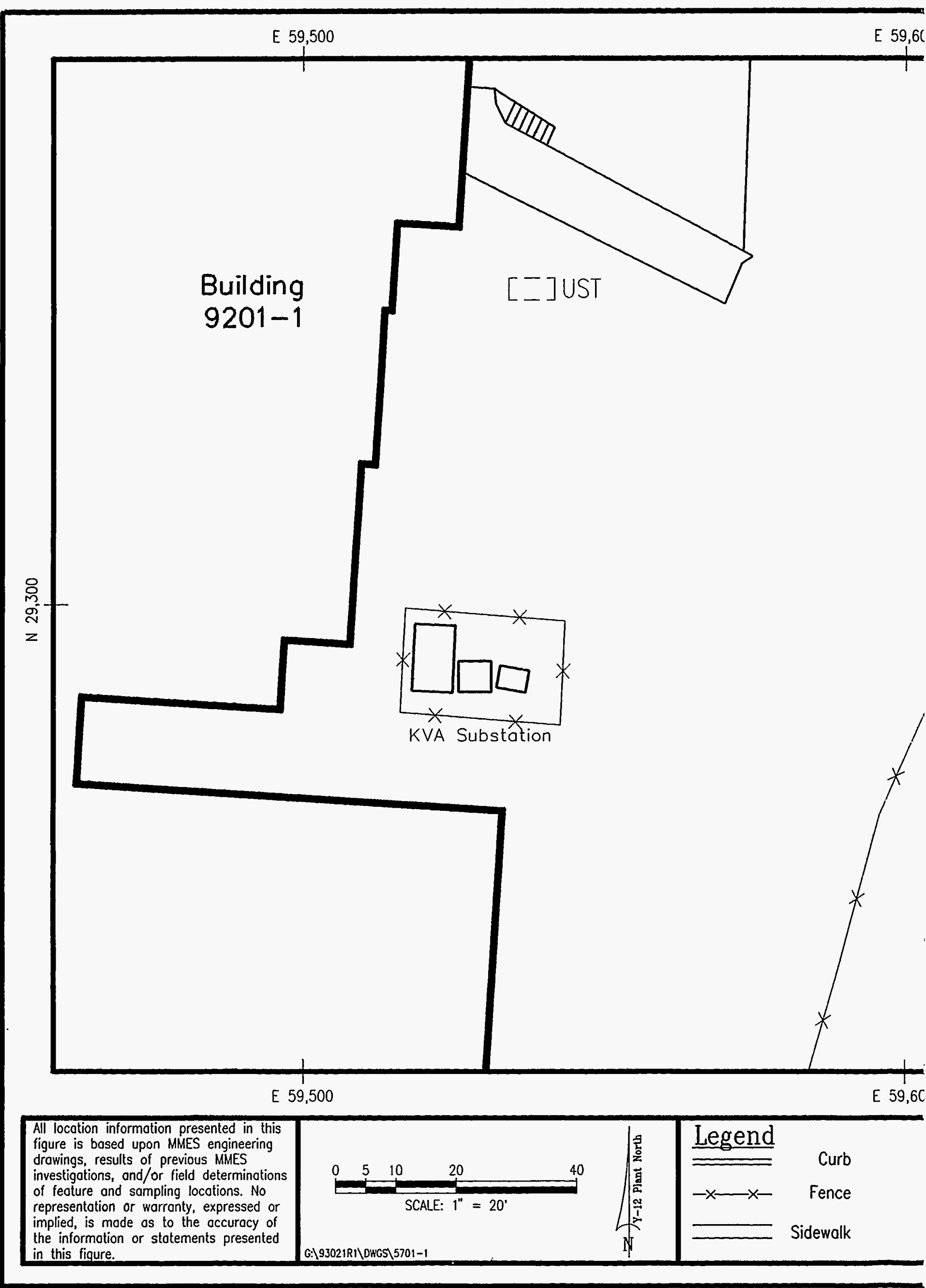




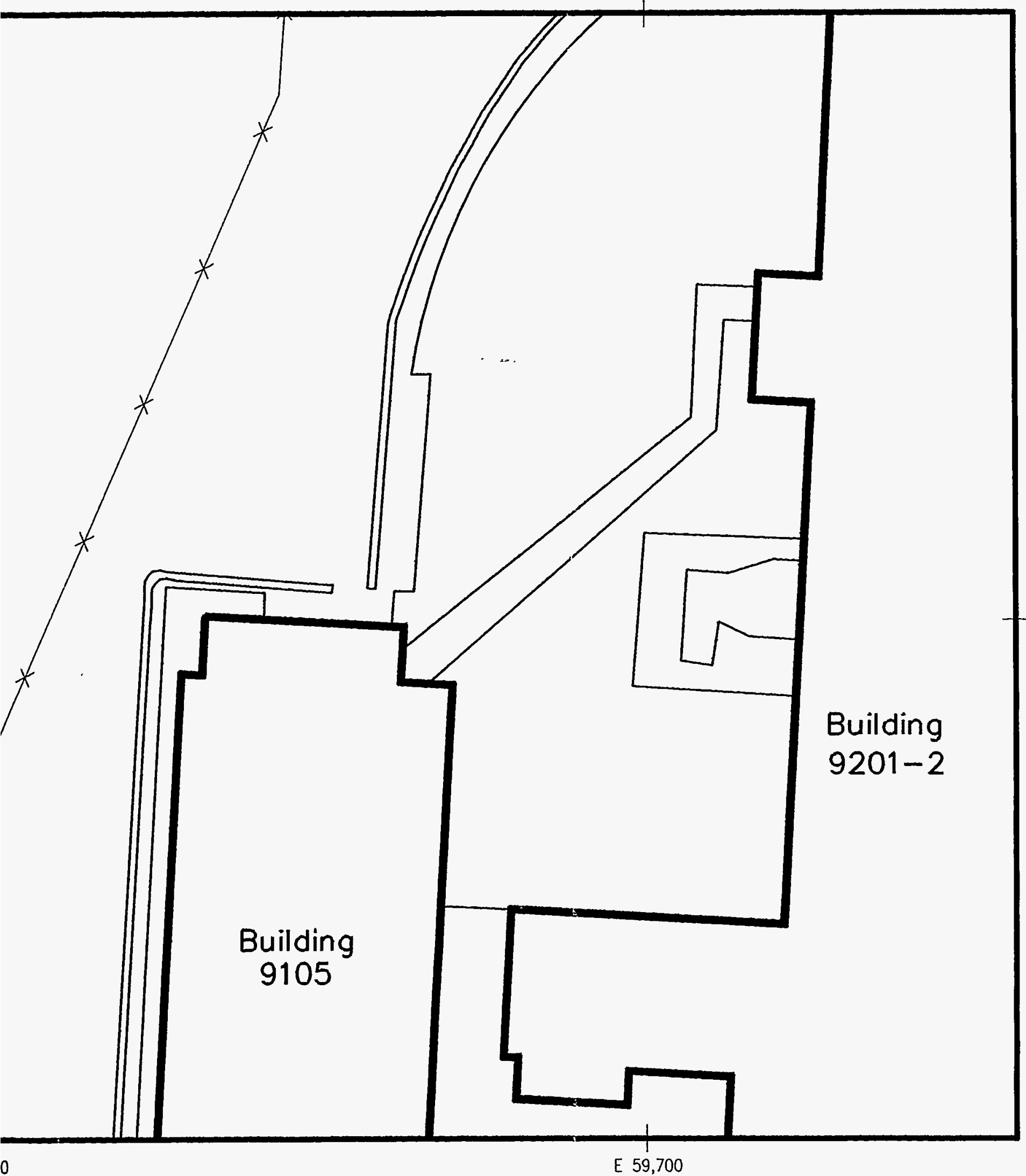

Martin Mariettó Energy Systems, Inc.

Environmental Management Department

\section{FIGURE 1-1}

Building 9201-1 Site Map 


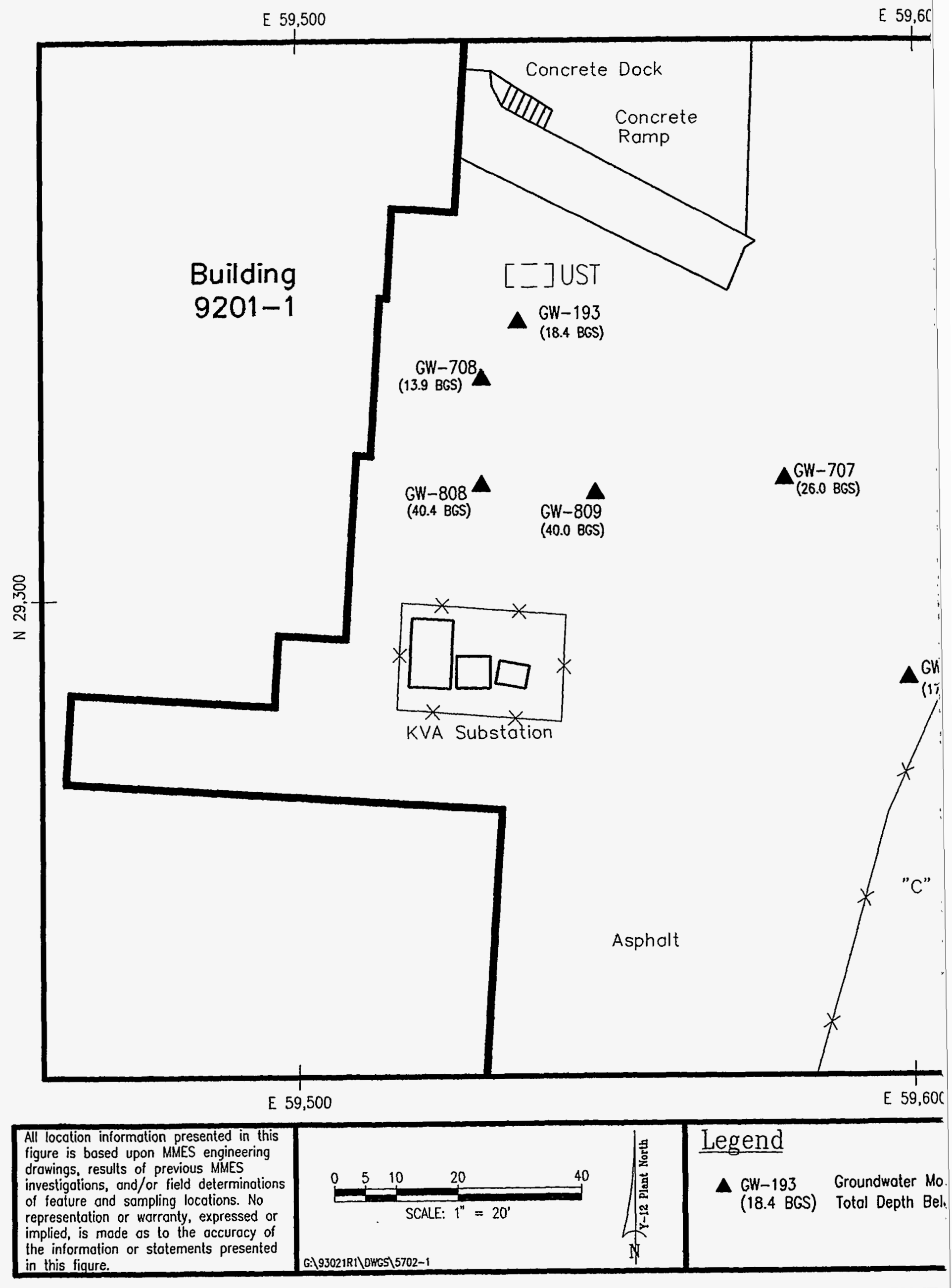




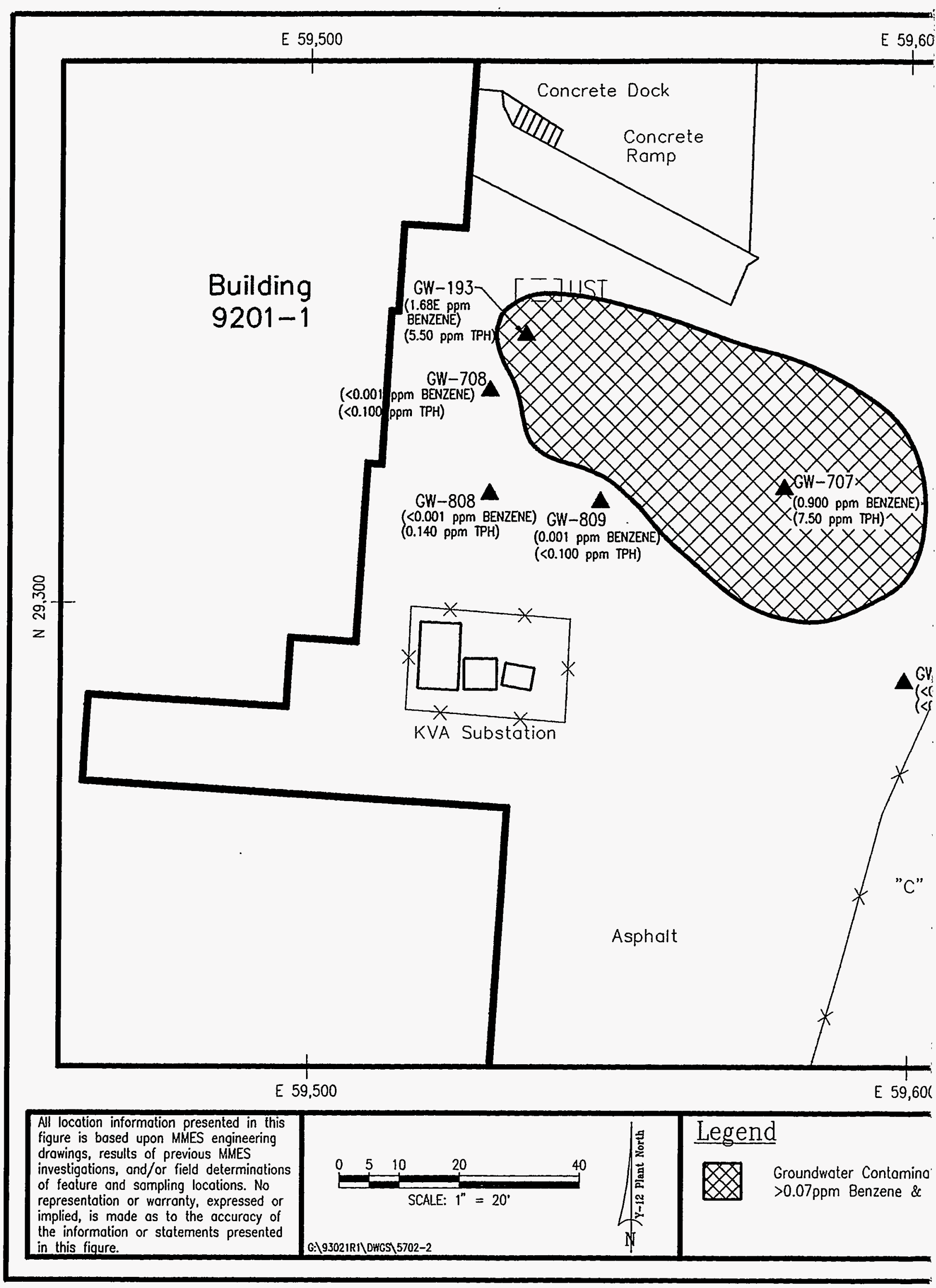




\section{E 59,700}

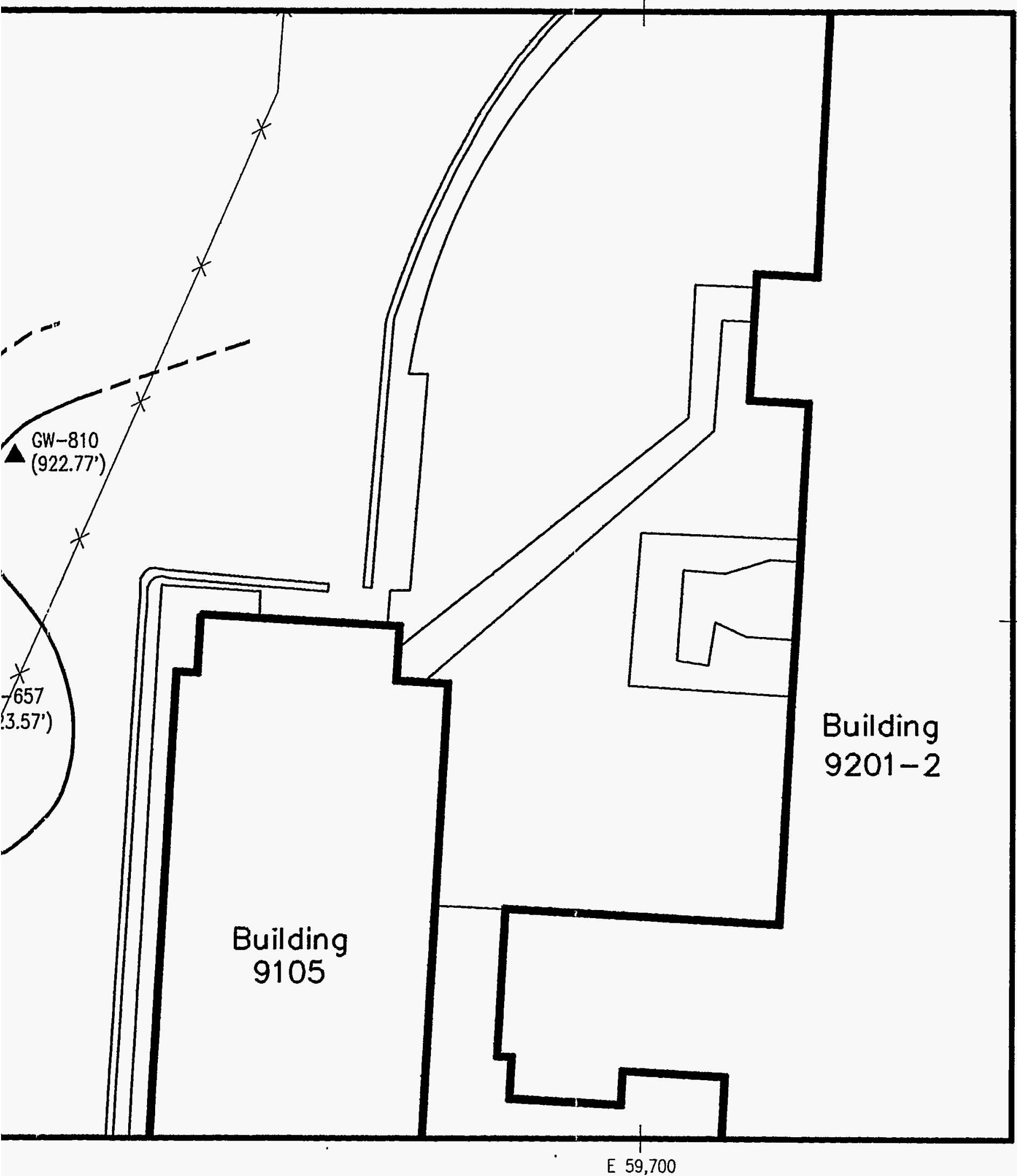

E 59,700

ometric Contour iL)

- Potentiometric Above MSL)
Martin Marietto Energy Systems, Inc. Environmental Management Department

$$
\text { FIGURE } 3-1
$$

Building 9201-1 Site

(925.29') Woter Level Meosurement Dec. 1993
Groundwater Potentiometric Contour Map Dec. 1993 


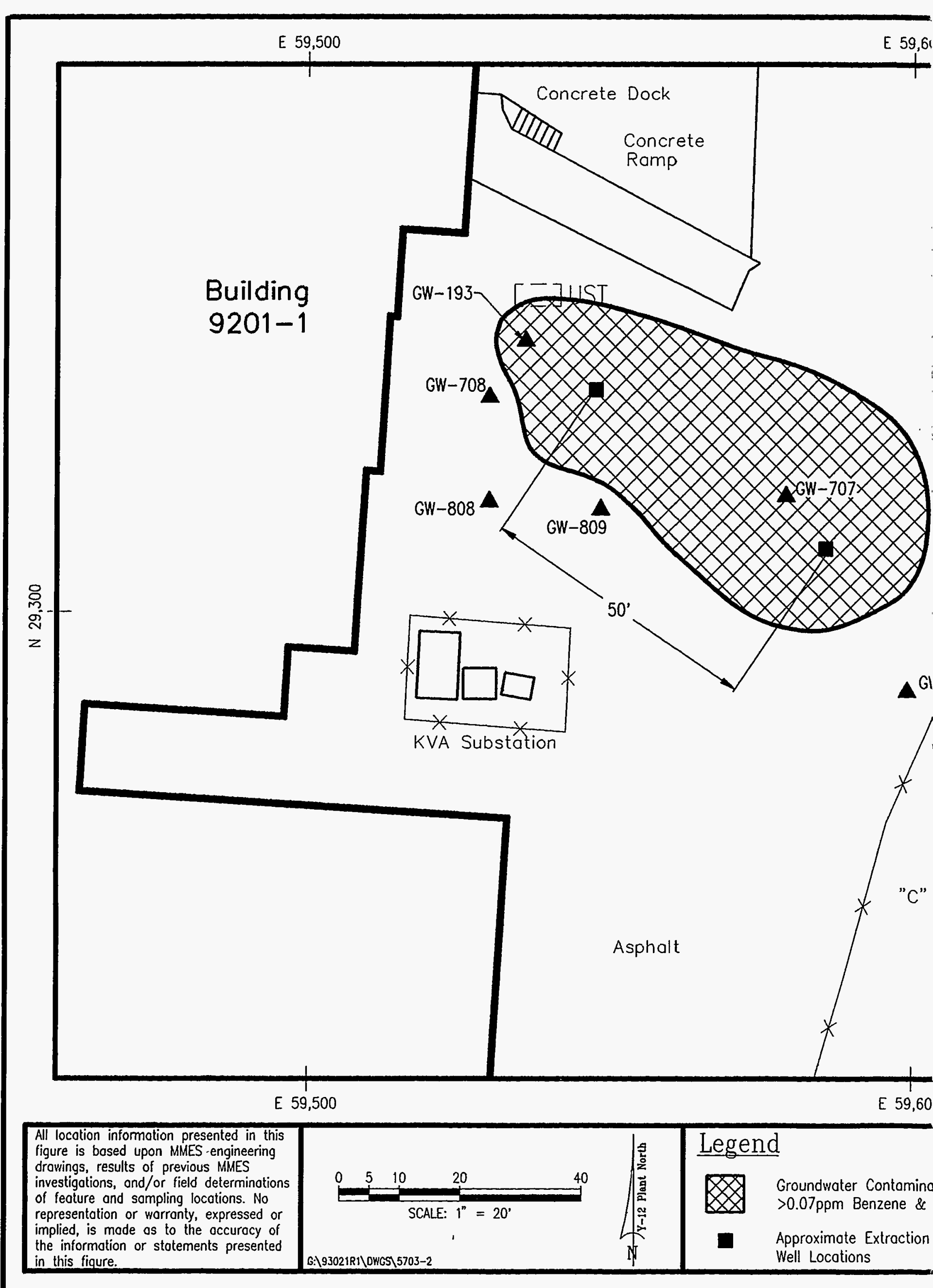




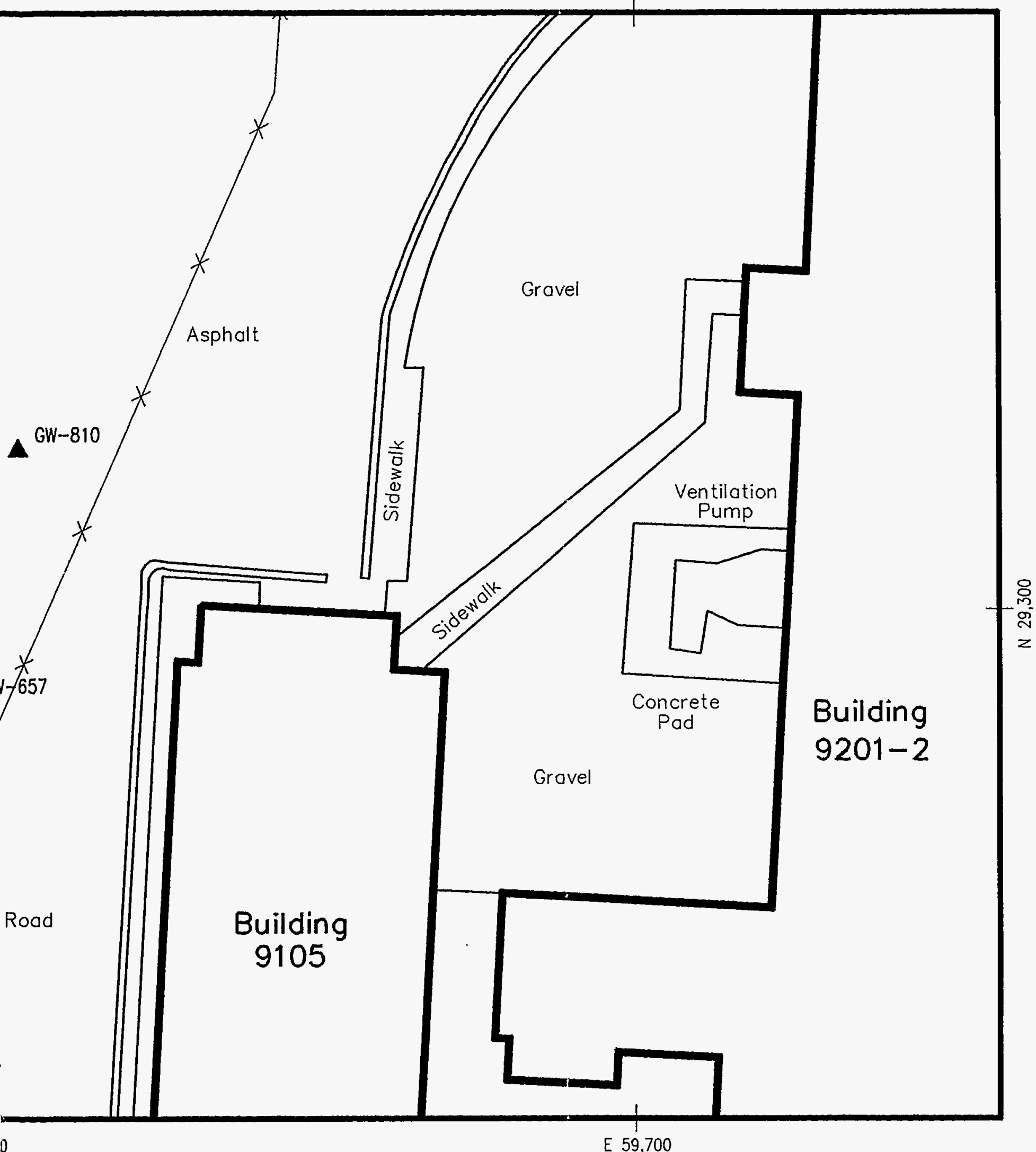

tion

$>1.0 \mathrm{ppm} \mathrm{TPH}$
Groundwoter Monitoring

GW-193 Well Locations
Mortin Morietto Energy Systems, Inc.

Environmental Management Department FIGURE $3-2$

Building 9201-1 Site Groundwater Extraction Well Locations 